University of Montana

ScholarWorks at University of Montana

$5-2000$

\title{
The Impacts of a Nonindigenous Marine Predator in a California Bay
}

\author{
Edwin D. Grosholz \\ University of California - Davis \\ Gregory M. Ruiz \\ Smithsonian Environmental Research Center \\ Cheryl A. Dean \\ Bodega Marine Laboratory \\ Kim A. Shirley \\ Bodega Marine Laboratory \\ John L. Maron \\ University of Montana - Missoula, john.maron@mso.umt.edu \\ See next page for additional authors \\ Follow this and additional works at: https://scholarworks.umt.edu/biosci_pubs \\ Part of the Biology Commons \\ Let us know how access to this document benefits you.
}

\section{Recommended Citation}

Grosholz, Edwin D.; Ruiz, Gregory M.; Dean, Cheryl A.; Shirley, Kim A.; Maron, John L.; and Connors, Peter G., "The Impacts of a Nonindigenous Marine Predator in a California Bay" (2000). Biological Sciences Faculty Publications. 342.

https://scholarworks.umt.edu/biosci_pubs/342

This Article is brought to you for free and open access by the Biological Sciences at ScholarWorks at University of Montana. It has been accepted for inclusion in Biological Sciences Faculty Publications by an authorized administrator of ScholarWorks at University of Montana. For more information, please contact scholarworks@mso.umt.edu. 


\section{Authors}

Edwin D. Grosholz, Gregory M. Ruiz, Cheryl A. Dean, Kim A. Shirley, John L. Maron, and Peter G. Connors 


\title{
THE IMPACTS OF A NONINDIGENOUS MARINE PREDATOR IN A CALIFORNIA BAY
}

\author{
Edwin D. Grosholz, ${ }^{1,4}$ Gregory M. Ruiz, ${ }^{2}$ Cheryl A. Dean, ${ }^{3}$ Kim A. Shirley, ${ }^{3}$ \\ John L. MARon, ${ }^{3}$ And Peter G. CONNORS ${ }^{3}$ \\ ${ }^{1}$ Center for Population Biology, University of California, Davis, California 95616 USA \\ ${ }^{2}$ Smithsonian Environmental Research Center, P.O. Box 28, Edgewater, Maryland 21037 USA \\ ${ }^{3}$ Bodega Marine Laboratory, P.O. Box 247, Bodega Bay, California 94923 USA
}

\begin{abstract}
Coastal marine ecosystems worldwide are being altered rapidly by the in vasion of nonindigenous species. Unlike terrestrial and freshwater systems, the impacts of an invading species have never been quantified on multiple trophic levels for a marine food web. We measured the impact of the nonindigenous green crab, Carcinus maenas, on a coastal marine food web in central California and found that this predator exerted strong "top-down" control, significantly reducing the abundances of several of the 20 invertebrate species monitored over a 9-yr period. Densities of native clams, Nutricola tantilla and Nutricola confusa, and native shore crabs, Hemigrapsus oregonensis, showed 5-fold to 10fold declines within $3 \mathrm{yr}$ of the arrival of green crabs. Field and laboratory experiments indicated that green crab predation caused these declines. We also tested for indirect responses of invertebrates and vertebrates to green crab predation. There were significant increases in the abundances of two polychaete taxa, Lumbrineris sp. and Exogene sp., and tube-building tanaid crustaceans, Leptochelia dubia, most likely due to the removal of cooccurring green crab prey. However, we observed no changes in shorebird abundances (13 species) over a 9-yr period suggesting that green crabs have had no "bottom-up" effect on shorebirds, which subsist on benthic invertebrate prey. We predict that such bottom-up control will occur as the local effects and geographic range of green crabs increase. The 2 -yr temporal scale of direct and indirect responses of the invertebrates in this low energy, soft-substrate system was also in agreement with the results of perturbation experiments by others on rocky shores, which showed that most direct and indirect responses also occur within a 2-yr time frame.
\end{abstract}

Key words: Carcinus maenas; European green crab; food webs; Hemigrapsus oregonesis; indirect effects; nonindigenous species; Nutricola spp.; predation; shorebirds; trophic levels.

\section{INTRODUCTION}

Introduced or nonindigenous species can represent a serious threat to the integrity of natural ecosystems. In some cases, they change community structure and ecosystem function on a large scale through the extinction of native species, alteration of fire regimes and rainfall patterns, changes in levels of primary production, and altered nutrient cycling and availability (Mooney and Drake 1986, Drake 1989, Hengeveld 1989, Vermeij $1991 a, b$, Groves and di Castri 1992, D'Antonio and Vitousek 1993, Case 1996, Vitousek et al. 1996). Many coastal estuarine and marine systems have proven particularly vulnerable to invasion, and literally hundreds of nonindigenous species have been reported from the most heavily invaded systems (Por 1978, Carlton 1985, 1987, 1989, 1992, Carlton and Geller 1993, Cohen and Carlton 1996, Ruiz et al. 1997). Unfortunately, in comparison with terrestrial and freshwater communities,

${ }^{4}$ Present address: Department of Environmental Science and Policy, University of California, One Shields Avenue, Davis, California 95616 USA. where the impacts of introduced species have been more extensively studied (Moyle et al. 1986, Ogutuohwayo 1990, Ogutuohwayo and Hecky 1991, Moyle and Leidy 1992, D'Antonio and Vitousek 1993, Schoener 1993, Case 1996, MacIsaac 1996, Schoener and Spiller 1996, Simberloff and Stiling 1996, Townsend 1996, Louda et al. 1997), our knowledge of the ecological impacts of introduced species in marine systems is comparatively limited. Therefore, we are currently unable to compare impacts among invasions in marine habitats, or to predict changes in these systems that might result from future invasions.

Most investigations of nonindigenous species in coastal systems have been concerned with the difficult and essential task of documenting the identities of invading species, and only a handful of studies have quantified any impacts of invading species on native biotas (Race 1982, Brenchley and Carlton 1983, Allmon and Sebens 1988, Posey 1988, Nichols et al. 1990, Lambert et al. 1992, Posey et al. 1993, Cloern 1996). With the exception of recent studies of Potamocorbula amurensis in San Francisco Bay (Alpine and Cloern 1992, Kimmerer et al. 1994, Cloern 1996), all previous studies of marine and estuarine systems have limited 
their investigations of invading species to either a single trophic level or to the benthos only. To date, no studies have measured the impacts of a nonindigenous species on both invertebrates and vertebrates in a fully marine system.

The recent invasion of the European green crab, Carcinus maenas (henceforth green crab), on the west coast of North America has provided a unique opportunity to quantify rigorously the impacts of a marine invasion on several trophic levels simultaneously. The green crab first became established along the western United States in San Francisco Bay, California, 1989-1990 (Cohen et al. 1995). In 1993, it first invaded our study site at Bodega Bay Harbor, California (henceforth $\mathrm{BBH}$ ), on the reserve of the Bodega Marine Laboratory of the University of California, Davis $\left(38^{\circ} 20^{\prime} 00^{\prime} \mathrm{N}\right.$, $\left.123^{\circ} 2^{\prime} 30^{\prime} \mathrm{W}\right)$. Currently, this species has expanded its range across $1600 \mathrm{~km}$ of western North America from Morro Bay, California, to Grays Harbor, Washington (Grosholz and Ruiz 1995, Grosholz 1996; E. D. Grosholz, unpublished data, J. Carlton and C. Mills, personal communication). We have collected data on the abundances of $>20$ species of benthic invertebrates and 13 species of shorebirds annually in $\mathrm{BBH}$, prior to, and after, the 1993 green crab invasion. These data provide a baseline for testing broad scale changes that may accompany the invasion of such a potentially significant predator (see Methods for review). In this study, we use this invasion as a novel test of theory regarding the potential for multitrophic level impacts as well as the relative magnitude of direct vs. indirect effects of the green crab in $\mathrm{BBH}$.

Predictions regarding the response of food webs to novel species yield conflicting answers. Studies in freshwater systems suggest that the introduction of a predator frequently results in changes in the abundance of organisms across many trophic levels, as with aquatic trophic cascades (Carpenter and Kitchell 1988, 1993, Power 1990, 1992). However, evidence from terrestrial systems suggests these multitrophic level responses may be less common in diverse and reticulate food webs where omnivory, allochthonous inputs, detritivory, and ontogenetic trophic shifts may dissipate multitrophic level responses (Strong 1992, Polis and Hurd 1996, Polis and Strong 1996). The BBH system represents a unique opportunity to examine these divergent predictions in a marine system.

The importance of indirect effects in structuring communities is now widely recognized. Many studies over the last $15 \mathrm{yr}$ have documented their consequences in a variety of communities (e.g., Davidson et al. 1984, Dethier and Duggins 1984, Dungan 1986, Schmitt 1987, Posey and Hines 1991, Strauss 1991, Wootton 1992, 1994a, Schoener 1993, Werner and Anholt 1996). Indirect effects have also been demonstrated in soft-sediment marine systems similar to $\mathrm{BBH}$ (Ambrose 1984, Commito and Ambrose 1985, Kneib 1988, Martin et al. 1989) where the high frequency of om- nivorous species may increase the likelihood of indirect interactions among species (Schoener 1989).

More recently, interest has focused not just on the existence of indirect effects, but rather the direction, time scale, and the relative magnitude and variation of both direct and indirect effects. This perspective has been advanced primarily by theoretical exploration of model food webs, producing a variety of predictions (Bender et al. 1984, Abrams 1987, 1992, 1995, Yodzis 1988, Abrams and Matsuda 1996, Holt 1996). These predictions suggest that indirect effects may potentially occur over longer time scales than direct effects (Bender et al. 1984, Yodzis 1988), and that indirect effects may produce changes that are as large as, or larger than, direct effects (Bender et al. 1984, Abrams 1987, 1992).

Many of these theoretical findings are now being tested empirically (Carpenter and Kitchell 1993, Schoener 1993, Holt and Lawton 1994, Menge 1995, 1997). In particular, recent literature surveys by Schoener (1993) and Menge $(1995,1997)$ are in general agreement about the relative timescales and magnitudes of direct and indirect effects. Schoener (1993), in his summary of six diverse food webs, found indirect effects were more variable in magnitude than direct effects, but found direct effects to be greater in magnitude in some studies and equal in magnitude in others. Menge (1995), in an examination of 23 rocky shore food webs, found that the magnitude of direct and indirect effects were generally equivalent, with each contributing $\sim 40 \%$ of the observed response to experimental perturbations. The time scale of direct and indirect effects was also similar between the two studies. Schoener (1993) found indirect effects concurrent with direct effects in one of three studies, and Menge (1997) found direct and indirect effects generally concurrent and occurred within two years of the experimental perturbation in nearly all of the rocky shore studies. We use these results to examine both the time scale and magnitude of direct and indirect effects in the BBH system that may be the result of the green crab invasion.

We measured the impact of the green crab invasion in $\mathrm{BBH}$ in two ways. First, we measured the impact of green crab predation on three different functional groups: infaunal invertebrates including suspensionand deposit-feeding molluscs and polychaetes, epifaunal invertebrates including decapod crustaceans, and vertebrate predators including wintering shorebirds. Defining trophic levels is difficult in this system because of the high levels of omnivory. For example, shorebirds prey on juvenile crabs, but they also share several prey taxa with crabs, so they could be included in the same group. In contrast, certain functional groups such as the infaunal invertebrate assemblage may contain more than one trophic level, as with tanaid crustaceans and some polychaetes that prey on other infauna (Reise 1979). Therefore, the three functional 
groups are considered to approximate only loosely the number of trophic levels in the BBH system.

Second, we quantified the time scale and magnitude of possible direct and indirect effects of predation by green crabs on both benthic invertebrates and wintering shorebirds in this system. This includes not only the direct effects of the introduced predator on prey species, but also species indirectly affected by the invader through interaction chains and interaction modifications (Wootton 1993, 1994b, Menge 1995, 1997).

To accomplish these goals, we combined long-term data and manipulative field and laboratory experiments to measure changes in benthic invertebrate and shorebird populations in $\mathrm{BBH}$ following the green crab invasion. We examined mechanistically the impacts of the green crab on its invertebrate prey through manipulative experiments and interpreted the broader changes throughout the harbor in the context of the longterm data. Using this approach, we measured the magnitude of the impact of green crab predation on different functional groups, as well as the time scale required for those changes.

\section{Methods}

\section{Study site and natural history}

Originally, the European green crab, Carcinus maenas (L.) (Crustacea: Portunidae) ranged from Norway to Mauritania. Much is known about the natural history of green crabs in their native range, as well the history of their invasion of several other locations, including in Australia, Japan, South Africa, and the eastern United States (reviewed in Cohen et al. 1995). Recent work suggests that some of these invasions including South Africa and Japan may include a sibling species, Carcinus aestuarii. However, the western United States invasion consists only of $C$. maenas (Geller et al. 1997).

Several previous studies of green crab predation in its native range have shown that the green crab may significantly reduce the abundance of invertebrate prey (Reise 1978, Scherer and Reise 1982, Gee et al. 1985, Jensen and Jensen 1985, Rangeley and Thomas 1987, Raffaelli et al. 1989). These and other studies from native habitats have demonstrated that green crabs have a broad diet range, but that bivalve molluscs generally make up the largest part of their diet.

Several studies of green crabs in their introduced ranges have suggested strong impacts on prey populations, but these effects have been coarsely quantified (MacPhail et al. 1955, Ropes 1968, Elner 1981, Malinowski and Whitlach 1983, Ropes 1988, Le Roux et al. 1990, Griffiths et al. 1992). However, such impacts are not unlikely, since green crabs are frequently abundant in their introduced range and consume a wide range of taxa, particularly molluscs and crustaceans (Ropes 1968, Elner 1981, Le Roux et al. 1990, Grosh-

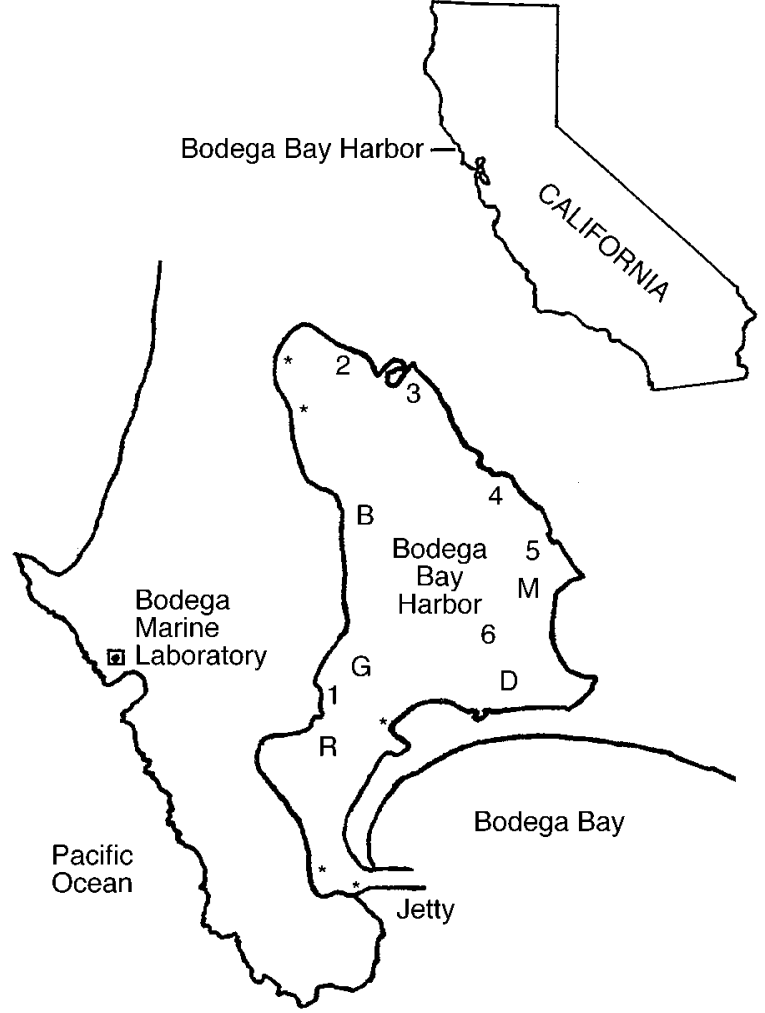

FIG. 1. Map of Bodega Bay Harbor (BBH) with the main sampling sites indicated by uppercase letters: $\mathrm{R}=$ Reserve, $\mathrm{G}=$ Gaffney, $\mathrm{B}=$ Boat Ramp, $\mathrm{M}=\mathrm{Marsh}$, and $\mathrm{D}=$ Doran. Additional sampling sites are indicated by numbers, and asterisks indicate sites in the harbor where no green crabs have been found. An inset of the state of California shows the location of BBH $\sim 100 \mathrm{~km}$ north of San Francisco.

olz and Ruiz 1995, Grosholz and Ruiz 1996, G. M. Ruiz, unpublished data).

The potential for measurable impacts of introduced green crabs on native species has been explored in detail at BBH (Grosholz and Ruiz 1995). In contrast to crabs in their native distribution in Europe, green crabs at $\mathrm{BBH}$ grow rapidly, reaching sexual maturity in their first year, frequently exceeding $80 \mathrm{~mm}$ in carapace width (vs. 50-60 mm. in native populations; G. M. Ruiz et al., unpublished data) in adult males. Our work has also shown that, in contrast to their native range, green crabs along western North America are restricted primarily to low-energy, soft-substrate habitats. Thus to date, they are unlikely to have impacts on rocky shores. Additional details of the life history of this species in western North America are contained in Grosholz and Ruiz (1995).

$\mathrm{BBH}$ is a marine embayment $\sim 2 \mathrm{~km}^{2}$ in area with a primarily sandy mud substrate (Fig. 1). The harbor receives little freshwater input and is largely flushed on each tidal cycle excepting small channels and a central dredged shipping channel. Consequently, the salinity in the harbor varies little throughout the year, and tem- 


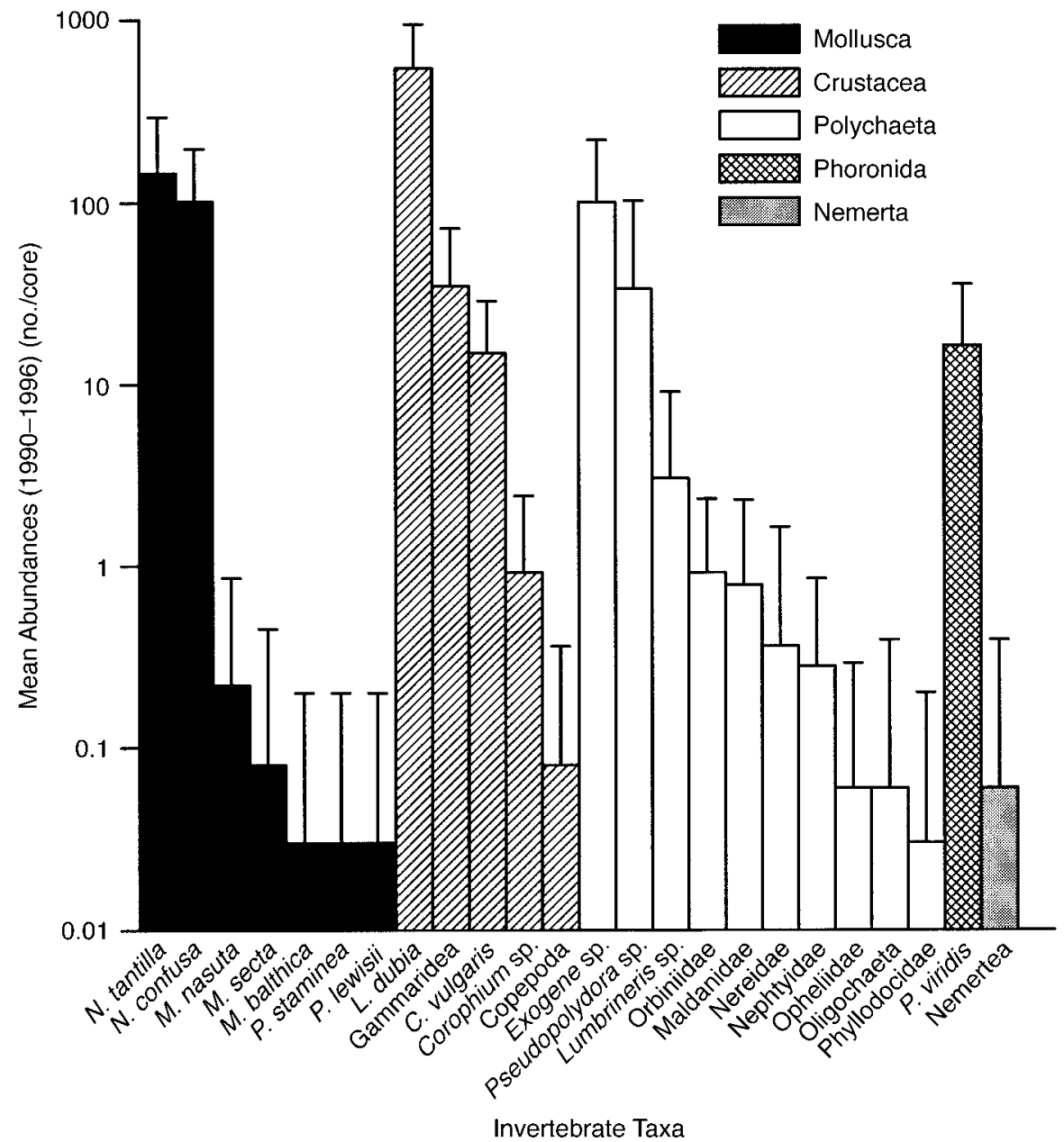

FIG. 2. Mean abundances of benthic invertebrates in core samples $(10 \mathrm{~cm}$ diameter $)$ at the Gaffney site from 1990 to 1996. Bar heights represent mean values (error bars $=1 \mathrm{SE}$ ) for all samples from tidal height $4(n=6)$ across years. Only taxa with abundances $>1$ individual/sample are included in subsequent analyses.

peratures generally reflect the range of ocean temperatures, $\pm 5^{\circ} \mathrm{C}$. The opening of the harbor is protected by a jetty, so the harbor is never swept by storm waves, nor is it ever closed off by sedimentation.

More than 20 species of benthic invertebrates are common in the upper few centimeters of the sandy, mudflat habitats of the Bodega Marine Laboratory reserve study site (Fig. 2). Among the most common are several species of bivalve molluscs, Nutricola (=Transennella) tantilla and Nutricola confusa, various crustaceans including grapsid crabs, Hemigrapsus oregonensis, the tanaid Leptochelia dubia, gammaridean amphipods, as well as numerous polychaete families and the phoronid, Phoronopsis viridis. The nonindigenous green crabs are the largest common intertidal predators. Larger native crabs (Cancer productus, C. antennarius, C. magister, $C$. gracilis) are primarily subtidal and only the first-year juveniles of these species are present intertidally, although none are normally abundant at BBH $(<1$ individual/pitfall trap, see Results).
At least 13 species of shorebirds are common throughout BBH from early fall through late spring, totaling as many as ten thousand birds at peak abundances (Fig. 3). These include Least and Western Sandpipers (Calidris minutilla and $C$. mauri), Semipalmated, Snowy and Black-bellied Plovers (Charadrius semipalmatus, C. alexandrinus, and Pluvialis squatarola), Dunlin (Calidris alpina), Long and Short-billed Dowitchers (Limnodromous griseus and L. scolopaceus), Willets (Catoptrophorus semipalmatus), Marbled Godwits (Limosa fedoa), Ruddy and Black Turnstones (Arenaria interpres and A. melanocephala), Sanderlings (Calidris alba), Killdeer (Charadrius vociferus), Red Knots (Calidris canutus), and Whimbrels (Numenius phaeopus). Most of these species leave the harbor in late spring to breed at higher latitudes during summer months. Previous studies quantifying the gut contents of some of the most common species such as Willets and Dunlin (Ruiz 1987) indicate that small, native clams, Nutricola spp., make up a large portion of their 


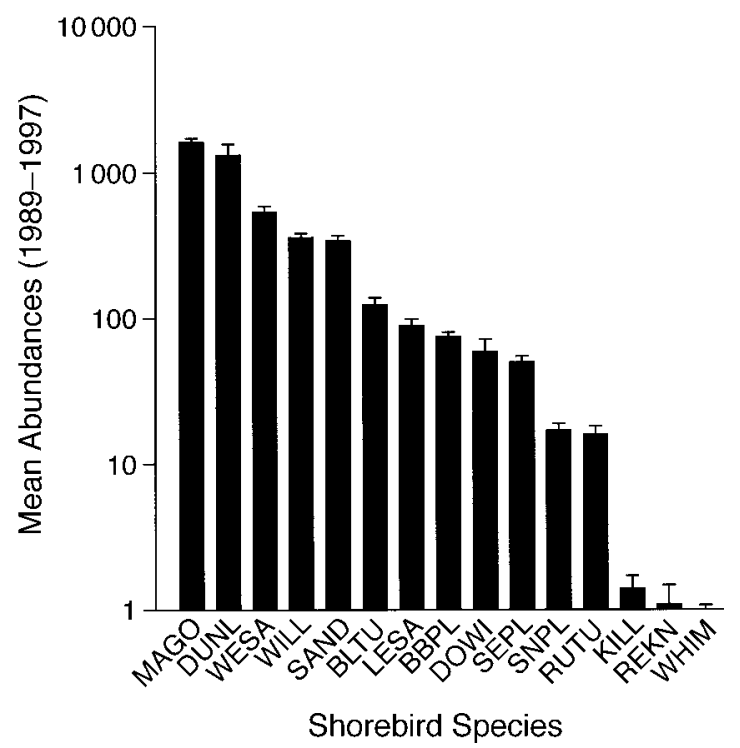

FIG. 3. Abundances of wintering shorebirds in annual counts from BBH from 1989 to 1997. Bar heights represent mean values (error bars $=1 \mathrm{SE}$ ) of all counts for that year (generally between 6 and 11). Counts do not include nonwading birds such as ducks, gulls, and pelicans. Only species with annual abundances $>10$, totalled for all species, are used in subsequent analyses. Abbreviations are as follows: MAGO $=$ Marbled Godwit (Limosa fedoa), DUNL = Dunlin (Calidris alpina), WESA = Western Sandpiper (Calidris mauri), WILL $=$ Willet (Catoptrophorus semipalmatus), SAND $=$ Sanderling (Calidris alba), BLTU = Black Turnstone (Arenaria me lanocephala), LESA = Least Sandpiper (Calidris minutilla) $\mathrm{BBPL}=$ Black-bellied Plover (Pluvialis squatarola), DOWI $=$ Long and Short-billed Dowitchers (Limnodromous griseus and L. scolopaceus), SEPL $=$ Semipalmated Plover (Char adrius semipalmatus), SNPL $=$ Snowy Plover $($ Charadrius alexandrinus), RUTU = Ruddy Turnstone (Arenaria inter pres $), \mathrm{KILL}=$ Killdeer (Charadrius vociferus) $\mathrm{REKN}=\mathrm{Red}$ Knot (Calidris canutus), and WHIM = Whimbrel (Numenius phaeopus).

diets, and thus, the diet of these birds may overlap substantially with green crabs.

\section{Green crab abundance}

Relative density.-To estimate changes in the relative density of green crabs, abundances of all crab species (Carcinus maenas, Hemigrapsus oregonensis, Cancer magister, $C$. productus, $C$. antennarius, $C$. gracilis) were estimated annually from 1989-1998, excluding 1992. Each year in late May-early June, at each of four tidal heights $(+0.3 \mathrm{~m},+0.6 \mathrm{~m},+0.9 \mathrm{~m},+1.2$ $\mathrm{m}$ MLLW) at the Gaffney site, we placed three pitfall traps $(20 \mathrm{~L}$ polyethylene buckets, $0.35 \mathrm{~m}$ deep $\times 0.3$ $\mathrm{m}$ diameter) at 50-m intervals along a transect parallel to the shoreline. Traps were buried in the sandy mud substratum with the top of the bucket flush with the substrate surface. Buckets acted merely as passive pitfall traps and were not baited, thus capturing crabs as they walked across the sediment surface. For all crabs, we recorded carapace width in millimeters, sex, and reproductive status by species. The summed total of three sampling days for each of the 12 pitfall traps (three traps at four tidal heights) was used for each year in subsequent statistical analyses.

Absolute density. - To estimate actual density of actively foraging green crabs, we estimated the abundances of green crabs visually two to three times annually from 1994-1996 at sites in BBH. Using snorkeling gear, along each of four transects at Gaffney (i.e., the four tidal heights as above), we recorded the numbers of actively foraging green crabs at high tide during the day. During each count, two observers counted all crabs (generally $H$. oregonensis and $C$. maenas) encountered along transects $(50 \mathrm{~m}$ long $\times 1$ $\mathrm{m}$ wide) delineated by a $1-\mathrm{m}$ rod held perpendicular to a 50-m lead-core transect line. Crab density estimates were based on the number of crabs counted per $50-\mathrm{m}^{2}$ transect.

The methods used were reasonably efficient for several reasons. First, the visibility in $\mathrm{BBH}$ is generally good $(2-3 \mathrm{~m})$ relative to the shallow water depth $(<2$ $\mathrm{m})$ over the census area. This allowed snorkelers to observe the larger adults that would occasionally flee in response to approaching snorkelers. Secondly, the 1 $\mathrm{m}$ long rods carried by the snorkelers were pushed along the substrate surface to flush the smaller crabs that either attempted to bury, were already buried, or were hidden by algae. On several occasions, we checked these methods by swimming transects twice or adding additional snorkelers. These checks indicated that our methods were reasonably efficient $(>90 \%$ of crabs collected).

At each census, most green crabs encountered were collected, and their carapace size and sex recorded. These counts were made on multiple days to increase sample size. Less frequent samples were taken at the Reserve site for comparison (Fig. 1). Day vs. night comparisons revealed no differences in abundances (see Results), although night counts may have been lower due to reduced visibility.

\section{Benthic invertebrate abundances}

To estimate the impact of green crabs on benthic invertebrates commonly found in $\mathrm{BBH}$, we followed changes in the abundances of $>20$ species. Invertebrate abundances were measured annually for $9 \mathrm{yr}$ between 1989 and 1998, excluding 1992. We used identical methods to sample infaunal taxa along four permanent transects (tidal heights $+0.3,+0.6,+0.9,+1.2 \mathrm{~m}$ above mean lower low water [MLLW]) on an intertidal sandy mudflat. To assess the impact of green crabs, we compared changes in abundances prior to 1994 with those from 1994 and afterward. We chose 1994 because this was the first year with an established population of adult green crabs (resulting from the 1993 juvenile cohort). Statistical tests for invertebrates used the actual counts (per trap or per core sample) from spatially fixed (approximate) replicates as independent variates. 
For each of the spatially fixed replicates, mean values were calculated across all years within a period (before or after 1994) to minimize temporal autocorrelation. Heteroscedastic variances required use of nonparametric methods to test for differences between means for the periods before and after the invasion.

Nutricola tantilla, N. confusa, and other invertebrates.-Over this same 9-yr period, the abundances of two species of small ( $<6 \mathrm{~mm})$ clams, Nutricola tantilla and Nutricola confusa, were also followed at the same study site (Gaffney) along the same four tidal heights used for measuring green crab abundances. In April of each year, a total of six core samples $(10 \mathrm{~cm}$ diameter $\times 5 \mathrm{~cm}$ depth) were taken at 20-m intervals along each of the four transects yielding 24 cores. All samples were processed with a $0.5-\mathrm{mm}$ sieve and fixed in $10 \%$ buffered formalin and later transferred to $70 \%$ EtOH for sorting and counting. For all taxa, counts for each of the cores each year were used in subsequent analyses. Statistical analyses include only taxa with mean densities $>1.0$ individuals/core (Fig. 2), and taxa with abundances below this level were generally too rare for meaningful statistical analysis. Data for some species are presently available only through 1996.

Harbor census. - To estimate changes in selected invertebrates at other sites in $\mathrm{BBH}$, we also performed an annual count at five sites around $\mathrm{BBH}$ using the same four tidal heights as the Gaffney site (see Fig. 1). Tidal heights were carefully referenced against the preexisting tidal heights at the Gaffney site. At each site, five core samples were taken at 20-m intervals along each of the four tidal transects. Each core was processed in the field with a larger mesh sieve $(1 \mathrm{~mm})$, which retains only adult Nutricola and other larger invertebrates. Our intention was to sample only a subset of the most common species that can be reliably counted and identified in the field without a dissecting scope. These included the two clam species mentioned above (Nutricola tantilla and Nutricola confusa), and three other species including another small bivalve (Gemma gemma), a polychaete (Nephytys caecoides), and the juvenile stages of an additional bivalve (Macoma balthica). Statistical comparisons were made among years for each combination of site and tidal height $(n=5$ cores/tidal height) using ANOVA. Data are presented for only tidal heights 1 and 2 where invertebrate abundances were highest, although the same patterns were evident at the higher tidal heights. Abundances were $\log$ transformed to meet the assumptions of ANOVA, and sample heterogeneity was tested with Cochran's $C$ test for sample variances (Winer et al. 1991).

\section{Shorebird abundances}

From 1989 to 1998, harbor-wide censuses were conducted to track the numbers of 13 species of wintering shorebirds (see Study site and natural history above). Census data were collected three times annually: an early season period (15 August to 30 September), a

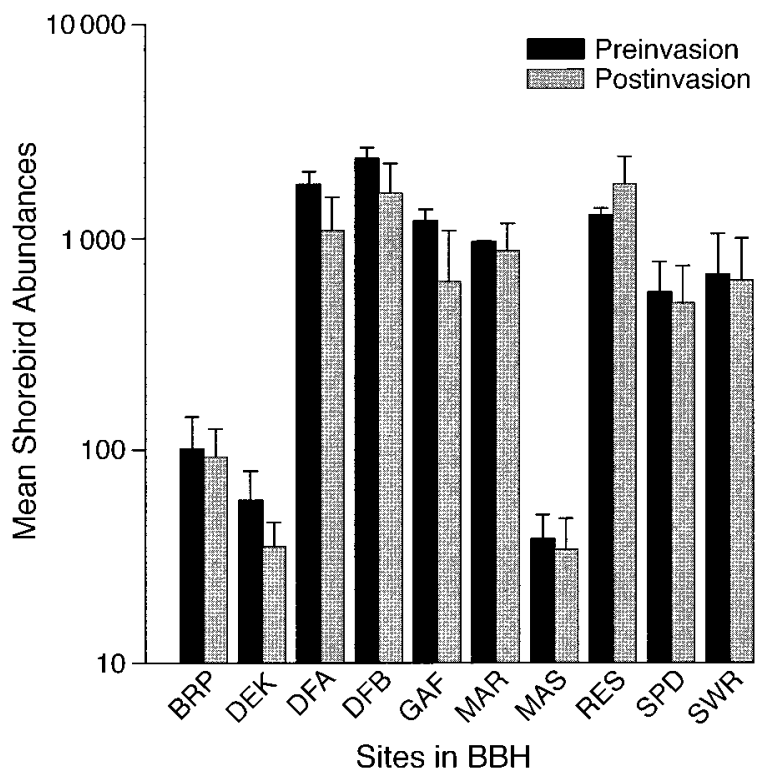

FIG. 4. Abundances of wintering shorebirds (not including ducks, gulls, and pelicans) at the 10 counting sites within Bodega Bay Harbor (BBH) for annual counts from 1989 to 1997. Preinvasion means include counts for all species pooled for years before the invasion (1994), and postinvasion means include counts for all species from 1994 to 1997 (error bars represent $+1 \mathrm{SE})$. Abbreviations are as follows for five sites that are the same as those for the invertebrate abundance census: Boat Ramp (BRP), Doran (DFA, DFB), Gaffney (GAF), Marsh (MAR), and Reserve (RES). There are four additional sites shown here: Diekmann's (DEK), Mason's (MAS), Spud Point (SPD), and Southwest Reserve (SWR).

midseason period (15 November to 31 December), and a late-season period (15 January to 28 February). These sampling periods were chosen to be frequent enough to capture the variation in bird abundances resulting from shorebird migration, but with enough time between counts to permit some measure of independence. During each sampling period, two to three replicate counts were made in which the entire harbor was censused by two or three people on days of approximately equivalent low tides (between +1.5 and +2.5 MLLW). Each count included estimates for all species with annual mean abundances $>10$ (Fig. 3). Harbor-wide counts represented the sum of counts at multiple sites in BBH (see Fig. 4), and each census was corrected for interharbor movement during the count by adding or subtracting birds as needed to account for movement between sites.

To test for changes in bird abundances before vs. after the green crab invasion, we calculated a mean abundance for each species for each of the three time periods (early, mid, and late season) in each year. We then compared these mean abundances before vs. after 1994 for each bird species and for all bird species combined using methods similar to those described above for invertebrates. Counts in different years were considered independent for this analysis, since most in- 
dividuals migrate to summer breeding grounds between annual counts. The analyses presented are based on the mid-season counts when shorebird abundances are greatest. This reduced the within-year variance due to migration and permitted a stronger test of differences among years.

We conducted a separate analysis to determine if the feeding location of shorebirds within $\mathrm{BBH}$ may have changed in response to the green crab invasion. During the harbor wide census described above, shorebird abundances were tallied separately for 10 sites around BBH (Fig. 4). We used these data to test for shifts in the use of foraging sites by shorebirds in BBH. To do so, we calculated a rank correlation for the mean abundance of all bird species at each of the ten sites before vs. after 1994.

\section{Predation experiments and diet analysis}

A series of experiments and measurements were used to test the hypothesis that the observed declines in the abundances of invertebrates witnessed at BBH after the green crab invasion were due to predation by green crabs. These included measurements of feeding rates in the laboratory and field, exclosure and enclosure experiments, and diet analysis.

Short-term predation rates.-To estimate predation rates of green crabs on shore crabs (Hemigrapsus oregonensis) in the field, we established experimental enclosures in the field at +0.6 MLLW between June and September 1995. Replicate enclosures were constructed from either inverted minnow traps or hardware cloth cages pushed into the sediment so as to enclose $\sim 0.3 \mathrm{~m}^{2}$. We established nine replicates of the following four treatments within a square six by six array (six rows and six columns to minimize distance among enclosures, each separated by $1 \mathrm{~m}$ ) by random assignment of replicates to enclosures: (1) one adult green crab ( $>60 \mathrm{~mm}$ carapace width) paired with one juvenile green crab $(<20 \mathrm{~mm})$ ( $+\mathrm{LGC}+\mathrm{SGC})$, (2) one adult green crab paired with one $H$. oregonensis similar in size to the juvenile green crabs $(<20 \mathrm{~mm})$ $(+\mathrm{LGC}+\mathrm{Ho}),(3)$ one juvenile green crab paired with one equivalently sized $H$. oregonensis ( $+\mathrm{SGC}+\mathrm{Ho})$, and (4) control treatments in which one juvenile green crab or one H. oregonensis was caged alone to evaluate survivorship and potential for escape from experimental enclosures (either $+\mathrm{SGC}$ or $+\mathrm{Ho}$ ). Once experiments were established, they were allowed to run for either 24 or $48 \mathrm{~h}$. All enclosures were checked daily for the presence of the crabs or the remains of body parts as evidence of predation. The proportions of each species surviving in the nine replicates of each treatment were compared with $G$ tests with equal expected frequencies for all treatments.

To estimate feeding rates of green crabs on Nutricola spp., we conducted timed feeding experiments in the laboratory using juvenile green crabs to determine the upper limit of feeding of green crabs on these small clams. The bottoms of 12 replicate plastic containers ( $\sim 1 \mathrm{~L}, 12 \mathrm{~cm}$ diameter) were covered with $\sim 3 \mathrm{~cm}$ of sieved $(0.5 \mathrm{~mm})$ sediment to which Nutricola $\mathrm{spp}$. were added. We placed 150 adult Nutricola spp. into the containers and allowed them to burrow into the sediment for a few hours prior to addition of the crabs. A single juvenile crab $(<40 \mathrm{~mm}$, replicates contained approximately equal numbers of both sexes) was added to each container and allowed to feed for $12 \mathrm{hr}$. Containers in which crabs molted soon after the experiment, or refused to eat, were excluded from the analysis. Maximum consumption rates were based on the number of clams remaining after the $12-\mathrm{hr}$ feeding period.

Green crab preferences were tested in a factorial design using Nutricola tantilla and Nutricola confusa (species treatment) of different size classes (size treatment). Using the same containers, size class of green crabs, and protocols as the maximum consumption rate experiment above, this experiment involved placing one green crab in each of 12 containers with 10 clams from each of three size classes (small 1-2.5 mm, medium 3-4 mm, large $>4 \mathrm{~mm}$ ) for both Nutricola tantilla and $N$. confusa (a total of 60 clams). The crabs were permitted to feed for $24 \mathrm{~h}$, after which all remaining individuals for each species and size class were counted. The arcsine-transformed proportion of clams consumed were compared by size class and clam species with ANOVA.

Diet analysis.-Gut contents were quantified for actively foraging green crabs that we collected at high tide while snorkeling. Crabs were collected from throughout the tidal range, but most commonly in zones corresponding to lower than $+0.5 \mathrm{~m}$ MLLW at low tide. Collected crabs were immediately placed on ice (within $10 \mathrm{~s}$ of collection) in a floating ice cooler that was towed beside collectors while snorkeling. Once crabs were brought ashore, typically within 20-30 min, they were immediately injected with $10 \%$ buffered formalin with the syringe tip inserted beneath the carapace. Crabs were later transferred to $70 \%$ alcohol and gut contents removed and identified to the nearest possible taxonomic category under a dissecting scope. Gut contents were tallied individually for each crab; data were the proportion of guts containing each taxon.

\section{Path analysis}

To analyze the strength of direct and indirect impacts of green crab predation in this community, we used path analysis on the abundance data for the BBH system. This technique has been used in ecological studies to partition the effects of direct and indirect effects in multispecies systems and to chose the best among alternative interaction web models of a given system (Schemske and Horvitz 1988, Wilbur and Fauth 1990, Mitchell 1992, Wootton 1994b). Unlike simple multiple regression, path analysis allows the a priori specification of causal pathways (see Pedazur 1982), pre- 
sumably based on an understanding of the natural history of the system. Thus, path analysis allows the construction of a model with causal pathways involving several independent and dependent variables. In comparison, the fixed structure of multiple regression allows only a single dependent variable. Also, path analysis permits the decomposition of the overall effect coefficient, which is the sum of the direct and indirect effects contributing to the correlation between two variables, into both causal and noncausal contributions. Once constructed, the path model allows the apportioning of direct and indirect interactions among species. For example, in the present study, a path analysis can permit the estimation of both the direct effects of green crab predation on their benthic invertebrate prey, as well as the indirect effects of green crab predation on species that are not directly consumed by green crabs, but that might compete with green crab prey. In contrast, multiple regression only permits the estimation of the direct effects of a causal variable, and does not permit the estimation of the indirect effects of one species on another.

The path model was constructed by first identifying all known or suspected causal pathways such as direct consumption or interference among pairs of species. Then for each causal pathway, a path coefficient was estimated as a standardized partial regression coefficient of the dependent variable on the independent variable (see Sokal and Rohlf 1981). This path coefficient indicates the magnitude of the direct effect of the independent variable on the dependent variable, while holding all other independent variables constant.

The choice of variables and the identity of the causal pathways chosen for inclusion in the path model strongly affect the results of the path analysis. The species included in the path model for the BBH system were the same ones presented in the sampling data, and are generally the most abundant taxa in $\mathrm{BBH}$; uncommon taxa were excluded from the model. The construction of causal pathways was based as much as possible on previous studies of the BBH community (Ruiz 1987), gut content data, and manipulative experiments. Additional inferences were based on examples from the literature and our own natural history observations at the site.

Because the number of taxa included in the model determines the degrees of freedom available to estimate the fit of the model, it was necessary to limit the number of variables included in the final set of models. For this reason, we grouped organisms into higher level taxa as follows: molluscs included Nutricola tantilla and Nutricola confusa; amphipods included Paraphoxus sp. and Eohaustorius sp.; polychaetes included Pseudopolydora sp., Exogene sp., and Lumbrineris sp.; and shorebirds included the total for the 13 species listed in Methods. These groupings were made in some cases because of trophic similarity and/or lack of data with which to separate species. For some shorebird species, such as willets and dunlin, we had diet data from BBH (Ruiz 1987), although diets for several other species at this site are unknown. Because path analysis is based on multiple regression and correlation, adherence to assumptions such as additivity, linearity, and uncorrelated residuals was required. In particular, inclusion of variables that are highly collinear must be avoided to reduce the sensitivity of the model to measurement errors. For instance, several of the shorebird and polychaete taxa had a high degree of collinearity within their respective group, and so were placed together as "shorebirds" or "polychaetes."

To estimate the path coefficients for the models selected for BBH, we used algorithms for structural equation analysis in SAS (Statistical Analysis Systems, Carey, North Carolina USA). This procedure, PROC CALIS, permitted the construction of path models with the LINEQ option by including a line in the model for each causal path. For each line entry in the model, a dependent variable is included in a single equation with the causal independent variables. Variables listed as independent variables in one equation could also be listed as dependent variables in another equation, but there was only one equation for each dependent variable.

The variables chosen for entry in the path analysis could be modeled as either endogenous or exogenous. Endogenous variables were those which were influenced by other variables in the model, while exogenous variables were influenced only by unknown variables not made explicit in the model. Therefore, exogenous variables were not dependent variables for other components in the system and had no causal paths pointing to them from other variables. All species in the $\mathrm{BBH}$ system were modeled as endogenous variables in subsequent analyses.

Path analysis also allowed the inclusion of residual variables, which represented variation in a particular variable due to unknown causes, and these were included in the model as a term in the equation for each dependent variable. Reciprocal causality between pairs of variables, for example in the case where one taxon was a causal variable for another and vice versa, could also be included in the path model by constructing two equations in which each species is an independent variable in the equation where the other was the dependent variable.

The data input for the model of BBH was determined by the matrix of Pearson product moment correlations (Table 1), which was generated with the Pearson option using the PROC CORR procedure. These correlations were calculated using square-root transformed abundances for each taxon from census data replicates for each year between 1990 and 1996. For the values of the residual variables (for each dependent variable in the model), we used the standard error for that variable for the entire period sampling period (1990-1996). These data were tested for multivariate normality to 
TABLE 1. Correlation coefficients (below main diagonal) and significance values of coefficients (above main diagonal) for taxa used in the path analysis. See text for description of groupings.

\begin{tabular}{ccccccccc}
\hline \hline Grouping & Moll & Poly & Tana & Phor & Amph & Hemi & Carc & Bird \\
\hline Moll & $\ldots$ & 0.0001 & 0.0001 & 0.110 & 0.0003 & 0.003 & 0.0003 & 0.559 \\
Poly & -0.737 & $\ldots$ & 0.0001 & 0.172 & 0.0001 & 0.026 & 0.0002 & 0.006 \\
Tana & -0.641 & 0.808 & $\ldots$ & 0.132 & 0.026 & 0.025 & 0.005 & 0.010 \\
Phor & 0.271 & -0.232 & -0.256 & $\ldots$ & 0.005 & 0.036 & 0.012 & 0.994 \\
Amph & 0.570 & -0.630 & -0.371 & 0.461 & $\ldots$ & 0.139 & 0.001 & 0.014 \\
Hemi & 0.483 & -0.371 & -0.374 & 0.351 & 0.251 & $\ldots$ & 0.002 & 0.020 \\
Carc & -0.564 & 0.589 & 0.462 & -0.416 & -0.516 & -0.490 & $\ldots$ & 0.688 \\
Bird & 0.101 & -0.447 & -0.425 & 0.001 & 0.407 & -0.386 & -0.069 & $\ldots$
\end{tabular}

Note $:$ Moll = molluscs (Nutricola spp.), Poly = polychaetes (Pseudopolydora sp., Exogene sp., and Lumbrineris sp.), Tana $=$ tanaids (Leptochelia dubia), Phor $=$ phoronids $($ Phoronopsis viridis), Amph $=$ amphipods $($ Paraphoxus $\mathrm{sp}$. and Eohaustorius sp.), Hemi = Hemigrapsus oregonensis, Carc = Carcinus maenas, Bird = shorebirds (13 spp. total).

meet the assumptions of this method of path analysis using the PROC UNIVARIATE module of SAS. Collinearity was tested using the COLLIN model option in PROC REG in SAS.

We chose the final model from among several competing models of the BBH system that differed in the number or identity of causal paths by adding or subtracting causal paths in a step-wise manner. The addition or subtraction of paths was conducted by adding or removing a given independent variable from the model equation for a given dependent variable. This permitted other causal paths involving that independent variable (with other dependent variables) to remain in the model. We varied causal pathways that were within the range of interactions given our understanding of the system, but we typically did not add or subtract interactions for which strong experimental or other evidence existed documenting that path. This was continued until all models from the initial list of probable models had been analyzed.

The output for the path analysis produced by the PROC CALIS model includes an estimated path coefficient for every combination of dependent and independent variables in the model as well as several estimates of overall fit of the model to the data. Both the values of these path coefficients and the fit of the model to the data were estimated using the unrestricted maximum likelihood option available in PROC CALIS module. To determine the statistical significance of the path coefficients, we used multiple regression in the PROC REG procedure for each set of dependent and independent variables. To choose the best fit model, we used a combination of two statistics: the smallest value of chi-square that describes the overall fit of the model to the data, and the smallest value of the Schwartz-Bayesian Criterion (SBC). This SBC criterion also measures model fit, but does so as a function of the degrees of freedom in the model. Two models with the same fit to the data will differ in their SBC such that the model with the smaller number of parameters and, therefore, degrees of freedom, will produce a smaller value for the SBC. The final model was the one that produced the best fit based on a combination of these two criteria.

\section{Environmental forcing}

Many measures of environmental changes are available for the University of California Bodega Marine Laboratory (BML), which is an official reporting station for the National Weather Service and is adjacent to our $\mathrm{BBH}$ site. Rainfall data for BML is available from the 1960 s to the present, which allowed us to determine if changes in rainfall and associated processes that would accompany increased runoff, such as increased siltation and nutrient loading, are related to the faunal changes observed. Rainfall is likely to be one the strongest environmental forces influencing West Coast bays and estuaries, and in particular, the increased rainfall associated with frequent El NiñoSouthern Oscillation events (Onuf 1977). Therefore, we used rainfall as a surrogate measure for environmental changes in this embayment.

To test for associations between environmental changes as measured by rainfall and the changes in the abundances of invertebrates and shorebirds between 1989 and 1998, we used a Spearman rank correlation test. For each taxon, we calculated a mean value for each year as described above, and tested for a correlation with the value for total rainfall (in centimeters) that year. We conducted the correlation separately for several of most common invertebrate species including the native shore crab, Hemigrapsus oregonensis, and the native clams Nutricola spp. For shorebirds, we pooled the abundances of all species for this analysis because of the similarities in the temporal trends of their abundances.

\section{RESUlts}

\section{Green crab abundance}

Relative density.-Our measures of the relative abundance of green crabs showed an approximately linear increase in relative density during the first four years (1993-1996) after their establishment $\left(r^{2}=0.96\right)$ (Fig. 5). From 1993 to 1996 , the mean number ( $\pm 1 \mathrm{SE}$ ) 


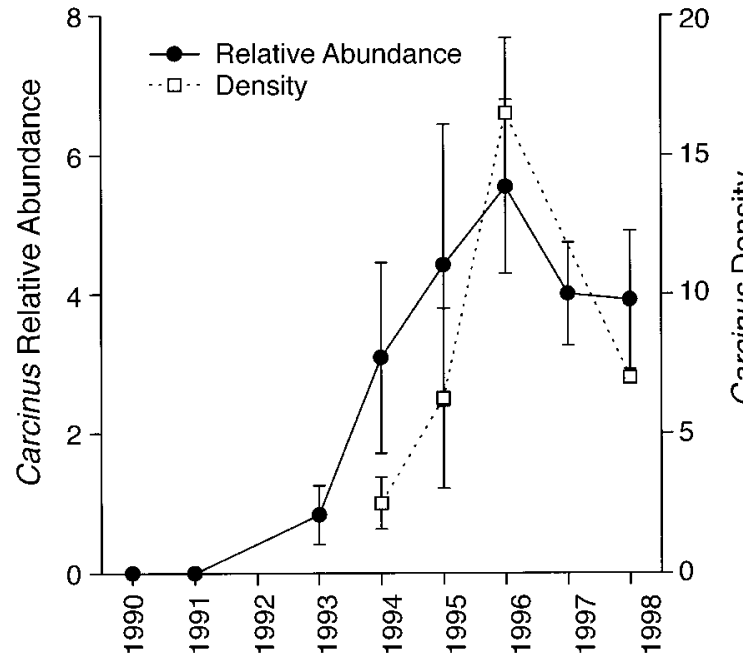

FIG. 5. Changes in the relative abundance (number of individuals/pitfall trap, solid circles) and density (number of individuals $/ 50 \mathrm{~m}^{2}$ transect, open squares) of the introduced European green crab, Carcinus maenas, from 1990 to 1998 in BBH. Symbols for each year represent mean values (error bars $= \pm 1 \mathrm{SE})$.

of green crabs per pitfall trap increased by more than $5 \times$ from $0.833 \pm 0.424$ to $5.5 \pm 1.25 \mathrm{crabs} / \mathrm{trap}(\mathrm{AN}$ OVA, $\left.F_{3,11}=3.43, P=0.025\right)$. These population increases stopped in 1996 (Fig. 5), however, and green crab abundances remained relatively constant thereafter (ANOVA, $F_{2,11}=0.78, P=0.46$ ).

Absolute density.-Absolute population density of green crabs also steadily increased from 1993 to 1996. Pooled data for (Gaffney plus Reserve sites) indicate that abundances of green crabs increased $4 \times($ ANOVA, $\left.F_{2,21}=5.58, P<0.05\right)$. Green crab counts did not differ between day and night (August 1994) (ANOVA, $\left.F_{2,9}=0.54, P>0.60\right)$. Diurnal differences were well within the range of variation seen on consecutive days at the same site. As with relative abundance estimates, absolute density did not increase from 1996 to 1998 .

\section{Benthic invertebrate abundances}

Hemigrapsus oregonensis.-The native shore crab Hemigrapsus oregonensis declined in mean abundance by nearly $10 \times$, a change that was coincident with the increase in abundance of green crabs from 1993 to 1996 (Fig. 6). Mean relative abundance of Hemigrapsus in pitfall traps differed before $(18.7 \pm 3.4 \mathrm{crabs} /$ trap $)$ and after $(2.04 \pm 0.46 \mathrm{crabs} / \mathrm{trap})$ the green crab introduction (Wilcoxon two-sample, $Z_{11,11}=4.072, P=$ $0.0001)$. Not only are mean abundance values for $H$. oregonensis much lower than those prior to the green crab invasion, they remained low for four consecutive years from 1995 to 1998 . This contrasts with the wide fluctuations observed prior to the introduction of green crabs. In addition, absolute density estimates based on subtidal counts also showed a $3 \times$ decline in $H$. ore-

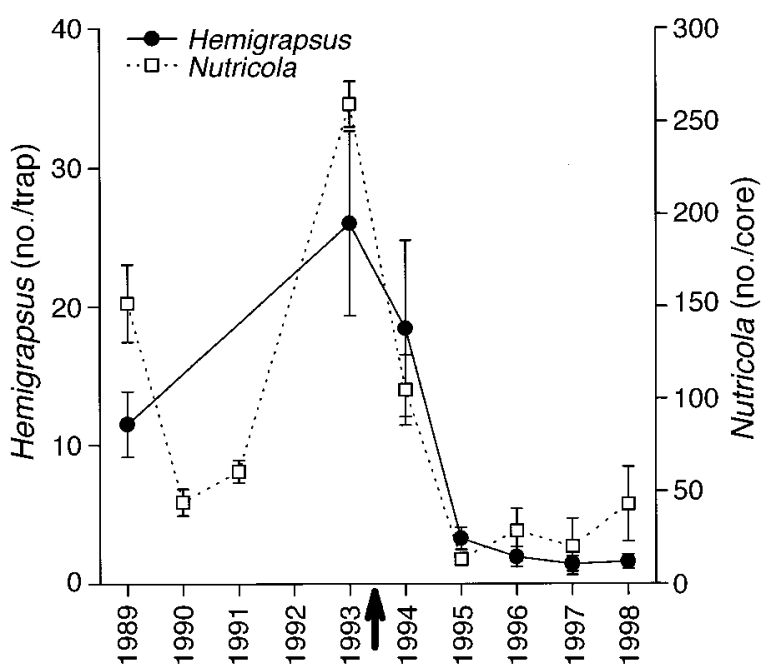

FIG. 6. Changes in the relative abundance of the shore crab Hemigrapsus oregonensis (solid circles) and the summed densities of the clams Nutricola tantilla and Nutricola confusa (open squares) from 1989 to 1998 in BBH. Symbols for each year represent mean values (error bars $= \pm 1 \mathrm{SE}$ ) of Nutricola (summed total) for the tidal height with the highest abundances (+0.6 MLLW). The invasion of the green crab in 1993 is indicated by the arrow.

gonensis from 1994 to 1996 (ANOVA, $F_{2,21}=4.73, P$ $<0.05)$.

Nutricola tantilla and Nutricola confusa.-Following the green crab invasion, we observed significant declines in the densities and/or relative abundance of several benthic invertebrate species at the Gaffney site, including the small native clams Nutricola confusa and N. tantilla (Fig. 6). In the first three years after the green crab invasion in 1993, Nutricola spp. declined nearly $5 \times$ in mean density (from $122.9 \pm 16.0$ to 26.2 \pm 4.4 clams/core) relative to years prior to the invasion (Wilcoxon two-sample, $Z_{5,5}=2.803, P=0.005$ ). These low densities, which have persisted for four consecutive years (Fig. 6), also contrast markedly with the wide fluctuations in previous years.

Other invertebrates.-Declines were also seen in other invertebrate taxa including gammaridean amphipods (Eohaustorius sp., Paraphoxus sp.) (Fig. 7), which declined during the period from 1994 to 1996 (Wilcoxon two-sample, $Z_{5,5}=2.647, P=0.008$. Not all invertebrates declined, though, as several polychaete taxa showed significant increases in abundance since the green crab invasion (Fig. 8). Using the same core data as for bivalves above, similar nonparametric tests showed spionids (Pseudopolydora sp., Wilcoxon two-sample, $Z_{5,5}=-2.486, P=0.013$ ) and syllids (Exogene sp., Wilcoxon two-sample, $Z_{5,5}=-2.803, P$ $=0.005)$ have increased $100 \times$ and $70 \times$, respectively, from 1994 to 1996. Tube-building crustaceans such as the tanaid, Leptochelia dubia, (Fig. 8) also increased $4 \times$ during the same time period (Wilcoxon two-sample, $\left.Z_{5,5}=-2.803, P=0.005\right)$. 


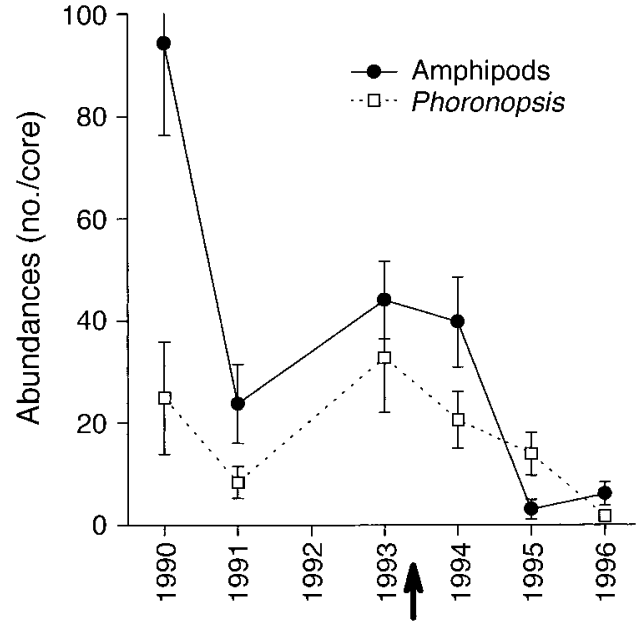

FIG. 7. Changes in the summed densities of the gammaridean amphipods Paraphoxus sp. and Eohaustorius (solid circles) and the densities of the phoronid Phoronopsis viridis (open squares) from 1990 to 1996 in BBH. Symbols for each year represent mean values (error bars $= \pm 1 \mathrm{SE}$ ) for the tidal height with the highest abundances (+0.6 MLLW). The invasion of the green crab in 1993 is indicated by the arrow.

Not all taxa showed significant changes during this period. Although the tube-building phoronid, Phoronopsis viridis, tended to decline after the green crab invasion (Fig. 7), these changes were not statistically significant (Wilcoxon two-sample $Z_{11,11}=1.041, P=$ $0.30)$. Phoronids appear to be distasteful to green crabs and in our short-term feeding attempts, we found that starved green crabs would rarely eat them (E. D. Grosholz, unpublished data).

Harbor census.-The patterns of abundance for the clams, Nutricola spp., at the main study site were generally repeated elsewhere throughout BBH (Fig. 9). Abundances declined at four of the five sites for both tidal heights 1 and 2 (see tidal heights in Methods) between 1994 to 1995 (Fig. 9). These reductions continued at three of five sites for both tidal heights in 1996, although there were obvious exceptions at the Marsh (tidal height 2) and Doran (tidal height 1) sites, where in some cases, abundances returned to, or exceeded, 1994 levels (see Fig. 9 for significance levels). Observationally, these increases in 1996 appeared due to large increases in the relative numbers of new recruits into the population following the declines of adults in 1995. The harbor census data did not include an analysis of the distribution of clams among size classes, so we cannot examine this possibility quantitatively.

\section{Abundances of shorebirds}

Since the green crab invasion, shorebird populations have remained unchanged (Fig. 10). This pattern holds both for all species pooled (Wilcoxon two-sample, $Z_{5,4}$ $=0.122, P>0.90)$, and for separate analyses of the most abundant species such as Dunlin, Marbled God-

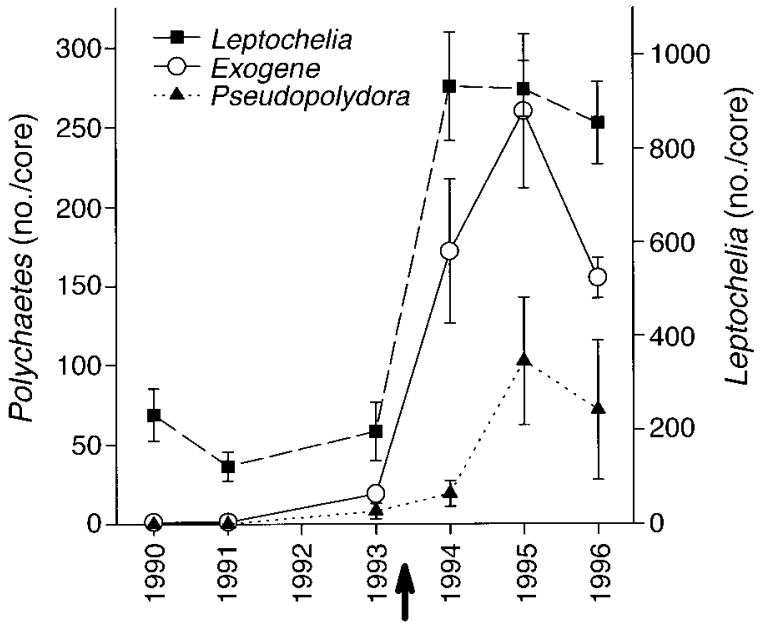

FIG. 8. Changes in the densities of two polychaetes, Pseudopolydora sp. (solid triangles) and Exogene sp. (open circles) and the tanaid Leptochelia dubia (solid squares) from 1990 to 1996 in Bodega Bay Harbor. Symbols for each year represent mean values (error bars $= \pm 1 \mathrm{SE}$ ) for the tidal height with the highest abundances (+0.6 MLLW). The invasion of the green crab in 1993 is indicated by the arrow.

wits, Western Sandpipers, and Willets (Wilcoxon twosample, Marbled Godwits, $Z_{5,4}=1.592, P>0.10$; Dunlin, $Z_{5,4}=-1.347, P>0.15$; Western Sandpipers, $Z_{5,4}$ $=0.857, P>0.30 ;$ Willets, $Z_{5,4}=1.837,0.05<P$ $<0.10)$.

To determine our ability to detect a decline in shorebird abundances given our sampling frequency, we calculated the power of detecting a single-year $40 \%$ decline from the average year with a sample size of $9 \mathrm{yr}$. Assuming an alpha value of 0.05 , we would have a probability $>80 \%$ of detecting such a decline for all shorebirds, and a $70 \%$ chance of detecting such a decline for Dunlin.

We found no evidence for changes in the abundances of shorebirds among the 10 foraging areas within $\mathrm{BBH}$ for which separate counts were available (see Fig. 4). In a test of the ranking of the number of birds at each of the 10 foraging sites before vs. after the invasion, we found a strong positive correlation (Kendall rank correlation, $r=0.95, P<0.0001)$ indicating no shift in the use of foraging sites coincident with the green crab invasion. There was a trend of increasing use of the Reserve site (RES) by shorebirds, while at many other sites including Doran (DFA, DFB), Gaffney (GAF), Marsh (MAR), there was a trend of declining usage. However, we found no significant changes when sites were analyzed individually $(t$ test, $P>0.20$ for all tests), or when all 10 sites were used together to test pre- vs. postinvasion counts (Wilcoxon two-sample, $Z_{10,10}=0.643, P=0.52$ ).

\section{Predation experiments and diet analysis}

In the field enclosures over the $24 \mathrm{~h}$ period of the trials, we found higher rates of predation by large green 


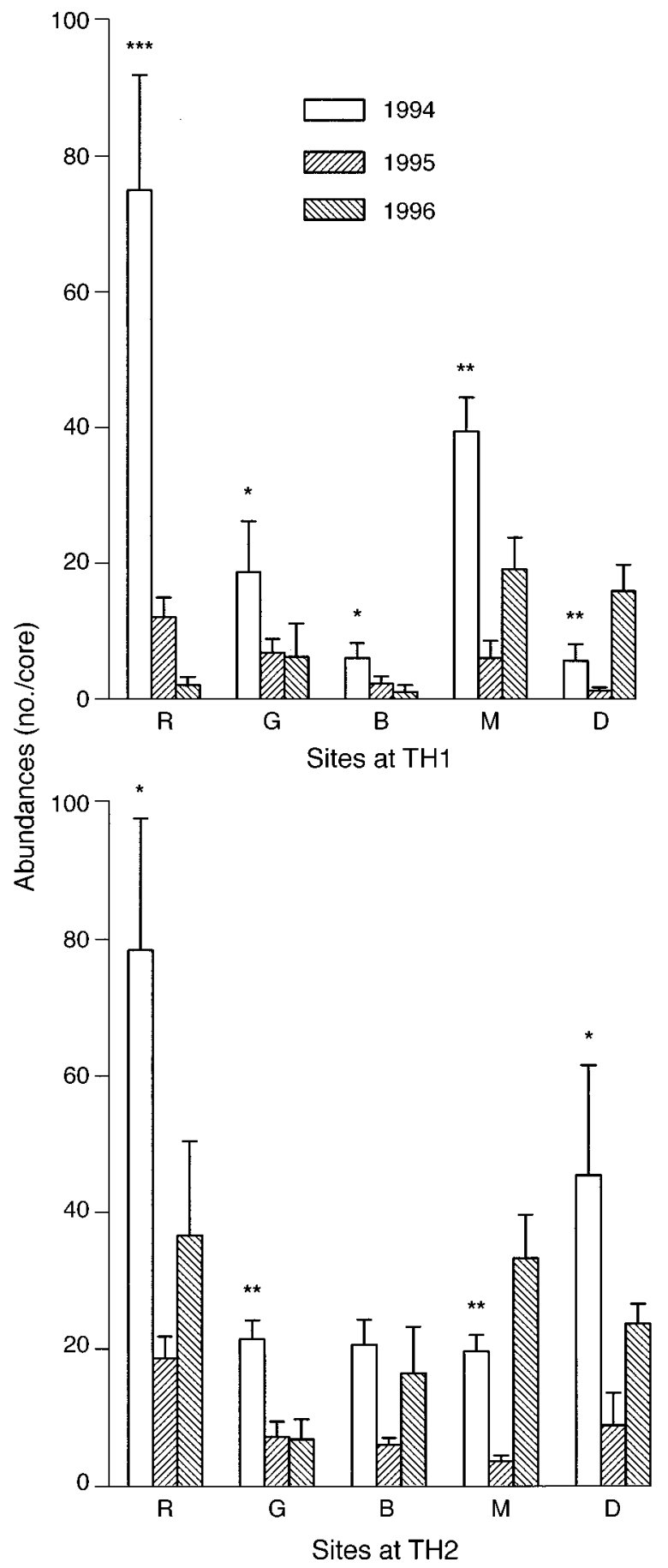

FIG. 9. Changes in the abundances of Nutricola spp. sampled and counted in the field at five sites $(\mathrm{R}=$ Reserve, $\mathrm{G}$ $=$ Gaffney, $\mathrm{B}=$ Boat Ramp, $\mathrm{M}=$ Marsh, $\mathrm{D}=$ Doran) around $\mathrm{BBH}$. The tidal heights $1(\mathrm{TH} 1=+0.3 \mathrm{MLLW})$ and 2 (TH2 $=+0.6$ MLLW) with the highest invertebrate densities are shown. Bar heights represent mean values (error bars $=1$ SE) for each year and site combination $(n=5)$ for that tidal height. Statistical significance of ANOVA (see Methods) of differences among years for each site and tidal height combination are denoted by asterisks above bars $(* P<0.05$, $* * P$ $<0.01, * * * P<0.001)$. crabs (adults $>60 \mathrm{~mm}$ carapace width) on adult Hemigrapsus oregonensis $(88.9 \%)$ than predation by large green crabs on juvenile green crabs comparable in size to adult $H$. oregonensis $(22.2 \%)\left(G_{\text {adj }}=8.69, P<\right.$ 0.005) (Fig. 11). Mortality in treatments with H. oregonensis and juvenile green crabs together was significantly lower (11\%), and there was no mortality in control enclosures where $H$. oregonensis or juvenile green crabs were placed alone $(n=18$ for these two treatments combined).

In several repeated laboratory feeding experiments, green crabs were able to consume up to the maximum numbers of clams offered them, usually in $<24 \mathrm{~h}$. For example, at the highest clam densities (150), juvenile green crabs $(<40 \mathrm{~mm}$ in carapace width) consumed virtually all of the 150 clams offered $($ mean $=145)$ in $12 \mathrm{~h}$. In the factorial experiment examining preference of green crabs for size (small, medium, large) and species (Nutricola tantilla, N. confusa), crabs had no preference for one clam species over the other (ANOVA, $\left.F_{1,66}=0.002, P=0.96\right)$. However, there was a strong preference for the larger sizes of both clam species (ANOVA, $F_{2,66}=29.2, P<0.0005$ ); there was no species by size interaction $\left(F_{2,66}=1.31, P=0.28\right)$.

The gut content analysis showed that the ranking of

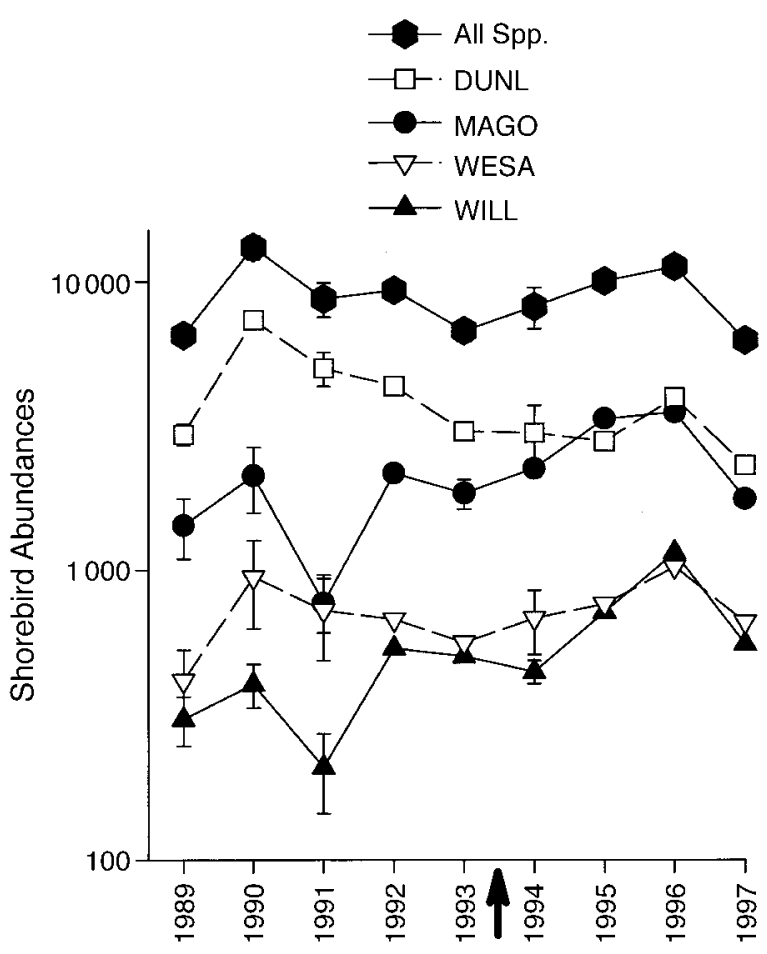

FIG. 10. Changes in the abundances of wintering shorebirds in BBH from 1990 to 1996 showing the total for all species (solid hexagons), Dunlin (DUNL, open squares), Marbled Godwits (MAGO, solid circles), Western Sandpipers (WESA, open inverted triangles), and Willets (WILL, solid triangles). Symbols for each year represent mean values (error bars $= \pm 1 \mathrm{SE}$ ). The invasion of the green crab in 1993 is indicated by the arrow. 


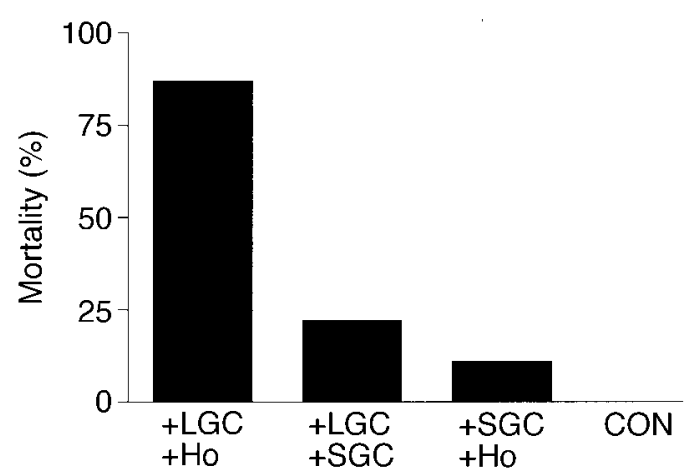

FIG. 11. Mortality in field enclosure experiments for Hemigrapsus oregonensis in treatments with adult green crabs $(+\mathrm{LGC}+\mathrm{Ho})$, and mortality of juvenile green crabs, Carcinus maenas, in treatments with either adult green crabs $(+\mathrm{LGC}+\mathrm{SGC})$ or with $H$. oregonensis of equivalent size $(+\mathrm{SGC}+\mathrm{Ho})$. Controls $(\mathrm{CON})$ indicate summed mortality of $+\mathrm{SGC}$ or + Ho when alone in enclosures. See Methods for full explanation of experimental design.

prey items was concordant with the taxa most frequently taken in field enclosures (Grosholz and Ruiz 1995), as well as with the declines seen in the longterm census studies (Fig. 12). Pieces of bivalve shell, most of which were identifiable as Nutricola sp., were the largest portion of the diet (53\%), other crustaceans, including amphipods and other crabs were the next most abundant (40\%), and other taxa such as polychaetes $(3 \%)$ were considerably less common.

\section{Path analysis}

The path model shown in Fig. 13 provided the best overall fit to the data based on the minimum chi-square and SBC values (see Methods). Path coefficients that were statistically significant are indicated with the arrow in bold. The model was consistent with green crabs having a strong direct negative effect on the abundances of Nutricola spp. and Hemigrapsus oregonensis. The model also suggests that the potential indirect effects of green crabs on polychaetes and tube building crustaceans may be mediated through the negative direct effects on Nutricola spp., which negatively affect these other species. The model is also consistent with the idea that shorebirds did not have a strong direct effect on Nutricola spp., although previous work has shown that shorebirds can substantially reduce clam abundance (Ruiz 1987). In this case, the model suggests that the relative strength of the direct effects of green crabs may be substantially larger than those of the shorebirds. Finally, the model is also consistent with the idea that the direct impact of green crabs on $\mathrm{Nu}$ tricola spp. does not result in a measurable indirect impact on shorebird populations. It suggests that although there is a direct impact of crabs on clams, the direct effect of clams on birds was not significant.

It is important to note that these results elucidate the relative strengths of indirect and direct pathways, but are not a demonstration of the underlying mechanisms. Instead, this model provides the basis for developing testable hypotheses, which may be experimentally verified in the future. The model produces the testable hypothesis that the impacts of green crabs may be acting both directly on Nutricola and through the negative impacts of Nutricola spp. on other infaunal species. This can be experimentally investigated in future studies.

\section{Environmental forcing}

None of the observed changes for bird and invertebrate populations were correlated with changes in locally measured physical variables. Heavy rainfall, which is associated with increased sediment loading and nutrient levels, occurred at $\mathrm{BBH}$ during El Niño (ENSO) events such as in 1995 (compare with 19821983 El Niño, Fig. 14). However, we found no association between rainfall measurements between 1989 and 1997 and abundance patterns (Spearman rank correlation, $P>0.15$ for Hemigrapsus, $P>0.30$ for $\mathrm{Nu}$ tricola spp., $P>0.60$ for shorebirds). Although the high rainfall in 1995 is coincident with the observed declines in benthic fauna, densities of most taxa were also very low in 1990-1991 (see Figs. 6-8), when rainfall was at the lowest level since 1977.

\section{DISCUSSION}

There is a clear pattern of change in the abundance of many benthic invertebrate species, especially those

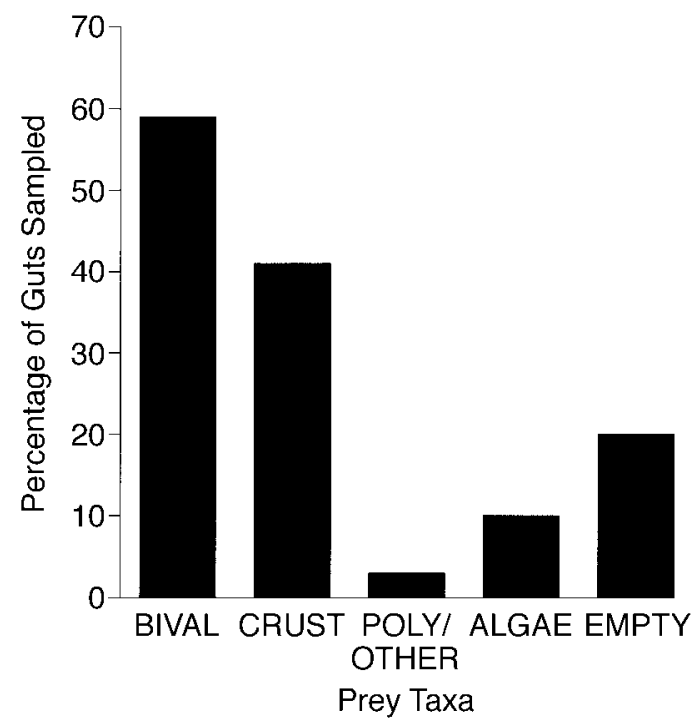

FIG. 12. The percentage of guts containing each of the listed prey items: BIVAL $=$ bivalve molluscs, CRUST $=$ crustaceans, POLY/OTHER $=$ polychaetes or other animal taxa, ALGAE = primarily green algae (Ulva sp.), and EMP$\mathrm{TY}=$ no prey. Guts were collected from actively foraging crabs and were fixed in the field $(n=30)$. Bar heights represent the percentage of guts containing that particular food item. 
FIG. 13. Path diagram of the BBH food web showing the trophic relationships between the taxa used for the path analysis. Arrows indicate direction of causality assumed in the model. Magnitude of path coefficients are adjacent to arrows designating that path (see Methods). Bold arrows indicate path coefficients that are statistically significant based on subsequent multiple regression analysis (the magnitude of the path coefficients do not predict statistical significance).

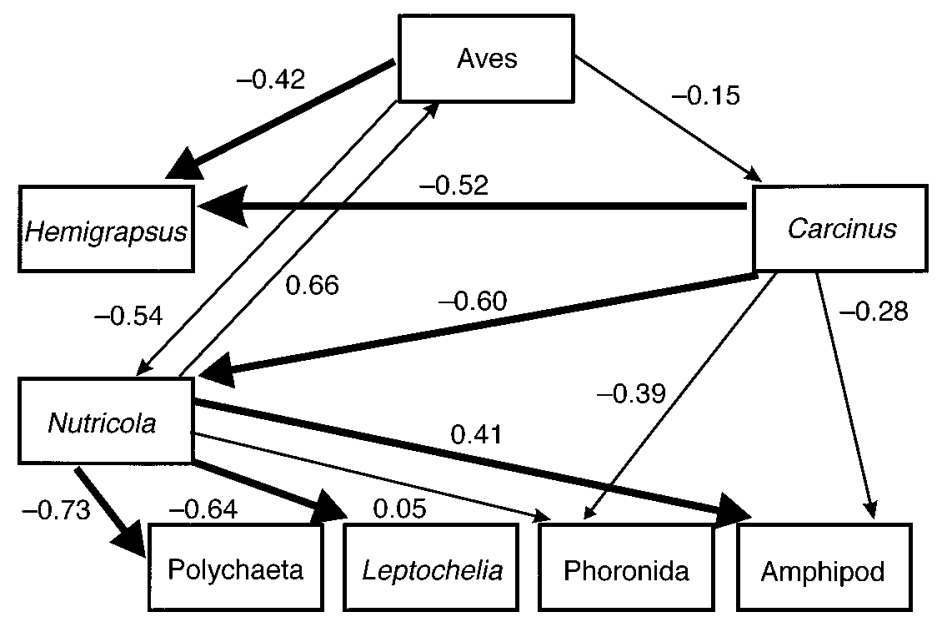

species that were numerically dominant in $\mathrm{BBH}$, and our data consistently support the hypothesis that predation by the invading green crab has been responsible for many, if not most, of the observed changes. The strongest support exists for the direct effect of green crabs on the clams Nutricola tantilla, N. confusa, and the crab Hemigrapsus oregonensis. The 5-10-fold declines in these native populations from the mean levels prior to the invasion coincide temporally with the invasion and increase of green crabs. Moreover, these low values have been sustained for four years since the green crab invasion, which represents a qualitatively different dynamic for these populations than had been observed in the preinvasion time series. In addition, multiple laboratory and field measurements support the hypothesis that this relationship between increasing crab density and decreasing clam density was causal. Several lines of evidence including gut contents, shortterm feeding experiments, manipulative exclosure/en-

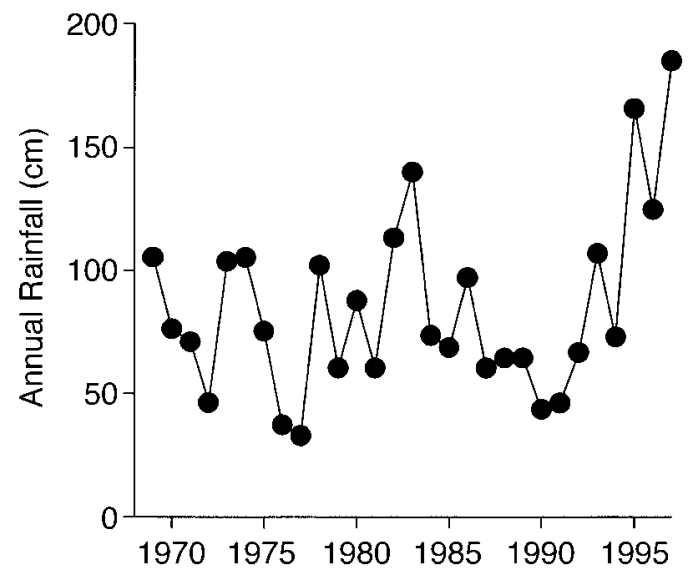

FIG. 14. Plot of annual rainfall for $\mathrm{BBH}$ as measured at the University of California Bodega Marine Laboratory for the National Weather Service. Each annual value is the cumulative rainfall for the period from 1 July of the preceding year to 30 June of that year. closure experiments, and behavioral observations all support the hypothesis that green crab predation was responsible for the harbor-wide changes in abundance. Although individual pieces of supporting evidence are by themselves insufficient, for instance enclosure experiments in the field and container experiments in the lab may magnify predation effects, these results taken together implicate green crab predation as the causal factor in the declining abundances.

Diet analyses indicate that three species, Nutricola tantilla, N. confusa, and Hemigrapsus oregonensis, are important prey of green crabs in $\mathrm{BBH}$, while laboratory and field experiments suggest that the invading crabs at current densities have the potential of causing the observed magnitude of declines. Our feeding experiments indicate that juvenile green crabs can consume up to 150 clams per day. Although container experiments may sometimes result in higher rates of predation, these results suggest that green crabs can potentially consume large numbers of clams. To illustrate, estimates using very conservative estimates of green crab abundance $\left(1 \mathrm{crab} / 10 \mathrm{~m}^{2}\right)$ and consumption rate of clams (50 clams per crab per day), and a high estimate of clam abundance $\left(2000 \mathrm{clams} / \mathrm{m}^{2}\right)$ indicate that green crabs could consume the entire clam population in $\sim 400 \mathrm{~d}$. While this calculation involves a number of assumptions including ignoring crab and clam recruitment and other prey species, it does illustrate the potential for green crabs to reduce populations of $\mathrm{Nu}$ tricola spp. to the low levels currently observed. In addition, green crabs are known to strongly affect bivalve populations in their native range (Reise 1977, 1978, Scherer and Reise 1982, Sanchez-Salazar et al. 1987), and appear to cause substantial declines of bivalves and grapsid crabs at invaded sites in both eastern North America and Australia (Ruiz et al.1997; W. Walton, personal communication).

Although the direct effects of green crabs on the prey species Nutricola spp. and Hemigrapsus oregonensis appear to be strong, the mechanism(s) responsible for 
increases of other taxa is still unclear. We hypothesize that these increases represent indirect effects associated with the green crab invasion. At present, this is supported only by the temporal association of increasing green crab abundance, subsequently decreasing prey abundance, and the increasing abundance of nonprey. Our data show that tanaids and polychaetes are not common prey of green crabs in $\mathrm{BBH}$, so direct effects of green crabs on these species appear improbable. Instead, we suggest that removal of Nutricola spp. by green crabs has allowed the non-prey species to increase, perhaps due to competitive release. From depthspecific core samples, we know that these species cooccur near the sediment surface (1-2 cm depth) and often achieve high densities, such that space competition may occur (Peterson 1982). No studies have investigated the mechanisms by which Nutricola may affect non-prey species, many of which form dense mats of tubes near the surface, but negative interactions between mobile infauna and sessile tube builders have been well documented elsewhere (Rhoads and Young 1970, 1971, Ronan 1975, Woodin 1979, 1981, Brenchley 1982). Although these studies identify a variety of competitive mechanisms, they have demonstrated that movement and feeding activities of mobile infauna such as bivalves can negatively affect survivival and recruitment of sessile tube builders, either through resuspension or disturbance of sediments.

We have also observed an increase in algal cover and the proportion of silt in the surface sediments of the Gaffney site, where the non-prey species increase has occurred (G. M. Ruiz and E. D. Grosholz, unpublished data). Although this change may be independent of green crab effects, we hypothesize that changes in both algal recruitment and sediment characteristics may also result from indirect effects of Nutricola spp. Another alternative, that increased algae and silt contributed to the observed declines of green crab prey, appear least likely. We measured declines of Nutricola spp. at several sites throughout the harbor (Fig. 9), while increases in algae and silt appeared to be restricted to a few patches in the lower intertidal areas of some sites. Furthermore, both species of Nutricola are commonly found in sediments with high silt content. In addition, our prior experience suggests that $H$. oregonensis is often very abundant in a broad range of sandy and muddy habitats along western North America, especially in the presence of algal cover. We view these alternatives as hypotheses which are not mutually exclusive. We are presently conducting experiments to test the effects of Nutricola spp. density on the surrounding community in order to determine whether the hypothesized indirect effects of green crabs are in fact operating through the direct effects of Nutricola spp.

We cannot identify any environmental change that can adequately explain the harbor wide decline of $\mathrm{Nu}$ tricola spp. or Hemigrapsus oregonensis. Beyond the observed changes in sediment and algal characteristics for a few locations at $\mathrm{BBH}$, we are not aware of other environmental changes that coincide with declines of these prey species. Although stochastic variation in larval recruitment levels can produce large variation in adult populations (Underwood and Denley 1984), this appears unlikely to explain observed changes for multiple reasons. First, the clams have direct development, and therefore, lack a planktonic larval stage. Second, the low abundance for Hemigrapsus is persistent, despite our qualitative observation of abundant postlarval crabs every spring before and after the green crab invasion.

Our data are sufficient to permit detection of moderate to large changes (see power analysis) in shorebird abundances, yet shorebird abundances have not changed since the green crab invasion at $\mathrm{BBH}$. This contrasts with an earlier study at $\mathrm{BBH}$, where shortterm declines in shorebirds coincided with more rapid and severe reductions in invertebrate prey than measured since the green crab invasion (Ruiz 1987). In 1985, larval recruitment for Dungeness crabs (Cancer magister) was extremely high at $\mathrm{BBH}$ and postlarval crabs were measured in excess of 4,000 crabs per pitfall trap per day (Everett 1989, Ruiz 1987); in comparison, we have measured $<10 /$ d for green crabs. The numbers of Dungeness crabs at $\mathrm{BBH}$ had returned to more typical levels within that year and have remained so ever since with counts of less than 1 crab per pitfall trap per day. Following this massive, short-term recruitment event, the abundances of many invertebrates plummeted (e.g., $<1$ Nutricola per core, see Fig. 6 for comparison), and there was a significant decline in shorebird abundances at BBH (Ruiz 1987; G. M. Ruiz, unpublished data). Shorebird declines were attributed to food limitation, resulting from direct effects of Dungeness crab predation on key shorebird prey species, and especially on Nutricola spp., which dominated the gut contents of some species such as Dunlin and Willets (Ruiz 1987, Ruiz et al. 1989).

In the case of the green crab invasion, the lack of response of shorebirds to the substantial declines in prey may result from any one or a combination of factors. It is instructive to compare the single trophic level response as a result of the green crab invasion with the multitrophic level response of the $\mathrm{BBH}$ system as a result of the Dungeness crab recruitment event. The increasing green crab densities from 1994 to 1996 were closely linked to declines in both clam and shore crab populations (Spearman rank correlation, $P<0.0005$ for Nutricola spp.; Spearman rank correlation, $P<0.01$ for Hemigrapsus). However, these declines in invertebrate densities differed from declines resulting from the Dungeness crab recruitment in two ways, 1) the declines occurred slowly over a period of two to three years rather than over two to three months after the Dungeness crab recruitment, and 2) the declines were smaller in magnitude (Ruiz 1987). This extended time scale (years vs. weeks) and lessened magnitude of in- 
vertebrate reductions in the green crab invasion may have allowed more time for behavioral changes, such as prey switching or exploitation of novel habitats to buffer changes in prey abundances. It is also possible that direct effects of green crabs have not yet crossed a density threshold necessary to create food limitation in shorebird populations (Goss-Custard 1981). Alternatively, a gradual decline may have allowed sufficient time for compensatory changes in biomass of invertebrates coincident with reductions of preferred prey taxa, as suggested by increases in polychaetes and tanaids (see Fig. 8). If shorebirds are able to adjust their diets to incorporate other invertebrates, no overall decline in food abundances may be experienced.

Although shorebird abundance has not declined, we cannot presently assess the potential indirect effects of green crabs on shorebird populations over larger temporal or spatial scales. It is difficult to measure the response of a local perturbation on such vagile species, which have relatively open local populations that can move large distances to compensate for local food reductions (Ruiz et al. 1989, Warnock et al. 1995, 1997). However, as the range of green crabs expands along the coast of western North America, prey resources may be reduced over a larger geographic area, thereby increasing the chances of both local and regional effects on shorebird populations in winter. Furthermore, effects of such food limitation may be especially acute during spring migration, when birds rely on readily accessible food resources for rapid energy gain to fuel northward migration and breeding (Warnock and Bishop 1998). However, these effects remain to be tested.

To date, only a handful of studies have measured the impacts of introduced species on coastal food webs on even a single trophic level, and most of these have been in estuarine rather than marine systems (e.g., Race 1982, Brenchley and Carlton 1983, Allmon and Sebens 1988, Posey 1988, Posey et al. 1993, see Ruiz et al. 1997 for review). Impacts at multiple trophic levels have been demonstrated for at least one estuarine species, the Asian clam Potamocorbula amurensis, in the San Francisco Bay. Several studies have shown that reduced phytoplankton production resulting from the filtering activities of high density clams has resulted in reduced copepod abundances with negative consequences inferred for fish predators (Alpine and Cloern 1992, Kimmerer et al. 1994, Cloern 1996). Our data examine the impacts of an exotic marine species on multiple trophic levels, thus providing the only data presently available to test predictions in a fully marine (vs. estuarine) system.

The time-scale of these changes in the densities of invertebrates in our study is consistent with changes resulting from experimental perturbations with native species on rocky shores (Menge 1997). The direct effects of green crab predation that resulted in rapid declines of invertebrates such as Nutricola tantilla, $\mathrm{Nu}$ tricola confusa, and Hemigrapsus oregonensis, and presumed to be responsible for declines in other taxa such as gammaridean amphipods, all occurred within two years of the establishment of adult green crabs in 1994 (first juvenile recruits in 1993). Similarly on rocky shores, most if not all direct effects of experimental perturbations including predator introductions occurred within two years (Menge 1997). Increases in tanaids and polychaetes, which we hypothesize to be the results of the indirect effects of green crab predation, also occurred within two years of the establishment of the green crab population. This is also consistent with the results from rocky shores where the indirect effects of experimental perturbations also occurred within two years of the manipulation (Menge 1997). A comparison of our results, in which both direct and possible indirect effects of green crab predation have occurred within two years of the green crab perturbation or introduction, with the one to two year response time for direct and indirect effects in rocky shores systems, suggests that the rapid recruitment and life history characteristics of intertidal invertebrates, rather than some physical feature of rocky shores, are largely responsible for the speed and concurrence of direct and indirect effects in these habitats. This is also consistent with broader emerging empirical findings that direct and indirect effects generally occur in approximately the same period of time (Schoener 1993, Menge 1997, Strong 1997).

In conclusion, our findings contribute to the debate surrounding the generality of multitrophic level changes in natural systems. Predictions about the response of food webs to novel species yield conflicting answers. Current views suggest that aquatic systems frequently display multitrophic-level responses to novel species, and that terrestrial systems rarely do so (Carpenter and Kitchell 1988, 1993, Power 1990, 1992, Polis and Hurd 1996, Polis and Strong 1996). At BBH, however, we have documented that the introduction of a novel predator, the green crab, produced changes at only lower trophic levels. Multitrophic-level responses in complex and reticulate food webs such as the $\mathrm{BBH}$ system are apparently rare, and have been documented only in response to extreme predation associated with the Dungeness crab recruitment event (Ruiz 1987). Therefore, we conclude that multitrophic level changes are apparently not a universal response of diverse marine food webs to introduced predators.

\section{ACKNOWLEDGMENTS}

We wish to thank numerous field assistants who helped with backbreaking work, in particular, B. Agius, E. Dionisio, D. Ginsburg, M. Greaves, D. Lauritzen, L. Nichols, and L. Rodriguez. We also thank M. E. Webster for endless hours counting invertebrates in benthic samples. We thank M. Bertness, A. Hines, B. A. Menge, J. P. Myers, F. Pitelka, W. Sousa, D. Strong, G. Vermeij, and two anonymous reviewers for discussions and/or improvements on the manuscript. Our work has been supported by N. S. F. Grant DEB-9322797 to E. D. Grosholz and G. M. Ruiz, funds from the Smithsonian Institution to G. M. Ruiz, and postdoctoral research support 
from the Center for Population Biology, U. C. Davis, to E. D. Grosholz. We would also like to thank the faculty and staff of the Bodega Marine Laboratory for travel funds and logistical assistance, and in particular, Don Strong, for his insight and help with competition for space in an increasingly space-limited world. Finally, we wish to the director of BML, Dr. James Clegg, for his continued support and interest in this work.

\section{Literature Cited}

Abrams, P. A. 1987. Indirect interactions between species that share a predator: varieties of indirect effects. Pages 38-54 in W. C. Kerfoot and A. Sih, editors. Predation: direct and indirect impacts on aquatic communities. University of New England Press, Dartmouth, New Hampshire, USA.

Abrams, P. A. 1992. Predators that benefit prey and prey that harm predators: unusual effects of interacting foraging adaptations. American Naturalist 140:573-600.

Abrams, P. A. 1995. Implications of dynamically variable traits for identifying, classifying, and measuring direct and indirect effects in ecological communities. American Naturalist 146:112-134.

Abrams, P. A., and H. Matsuda. 1996. Positive indirect effects between prey species that share predators. Ecology 77:610616.

Allmon, R. A., and K. P. Sebens. 1988. Feeding biology and ecological impact of an introduced nudibranch, Tritonia plebeia, New England, USA. Marine Biology 99:375-385.

Alpine, A. E., and J. E. Cloern. 1992. Trophic interactions and direct physical effects control biomass and production in an estuary. Limnology and Oceanography 37:946-955.

Ambrose, W. G. 1984. Influence of predatory polychaetes and epibenthic predators on the structure of a soft-bottom community. Journal of Experimental Marine Biology and Ecology 81:114-145.

Bender, E. A., T. J. Case, and M. E. Gilpin. 1984. Perturbation experiments in community ecology: theory and practice. Ecology 65:1-13.

Brenchley, G. A. 1982. Mechanisms of spatial competition in marine soft-bottom communities. Journal of Experimental Marine Biology and Ecology 60:17-33.

Brenchley, G. A., and J. T. Carlton. 1983. Competitive displacement of native mud snails by introduced periwinkles in the New England intertidal zone. Biological Bulletin 165:543-558.

Carlton, J. T. 1985. Transoceanic and interoceanic dispersal of coastal marine organisms: the biology of ballast water. Oceanography and Marine Biology Annual Review 23: 313-374.

Carlton, J. T. 1987. Patterns of transoceanic marine biological invasions in the Pacific Ocean. Bulletin of Marine Science 41:452-465.

Carlton, J. T. 1989. Man's role in changing the face of the ocean: biological invasions and implications for conservation of near-shore environments. Conservation Biology 3:265-273.

Carlton, J. T. 1992. Introduced marine and estuarine mollusks of North America: an-end-of-the-20th-century perspective. Journal of Shellfish Research 11:489-505.

Carlton, J. T., and J. B. Geller. 1993. Ecological roulette: the global transport of nonindigenous marine organisms. Science 261:78-82.

Carpenter, S. R., and J. T. Kitchell. 1988. Consumer control of lake productivity. Bioscience 38:764-769.

Carpenter, S. R., and J. F. Kitchell. 1993. The trophic cascades in lakes. Cambridge University Press, Cambridge, UK.

Case, T. J. 1996. Global patterns in the establishment and distribution of exotic birds. Biological Conservation 78: 69-96.
Cloern, J. E. 1996. Phytoplankton bloom dynamics in coastal ecosystems: a review with some general lessons from sustained investigations of San Francisco Bay, California. Review of Geophysics 34:127-168.

Cohen, A. N., and J. T. Carlton. 1996. Nonindigenous species in a United States estuary: A case history of the ecological and economic effects of biological invasions in the San Francisco and Delta region. Report to U. S. Fish and Wildlife Service, Washington, D. C., USA.

Cohen, A. N., J. T. Carlton, and M. C. Fountain. 1995. Introduction, dispersal, and potential impacts of the green crab Carcinus maenas in San Francisco Bay, California. Marine Biology 122:225-238.

Commito, J. A., and W. G. Ambrose. 1985. Multiple trophic levels in soft-bottom communities. Marine Ecology Progress Series 26:289-293.

D'Antonio, C. M., and P. M. Vitousek. 1993. Biological invasions by exotic grasses, the grass/fire cycle, and global change. Annual Review Ecology and Systematics 23:6387.

Davidson, D. W., R. S. Inouye, and J. H. Brown. 1984. Granivory in a desert ecosystem: experimental evidence for indirect facilitation of ants by rodents. Ecology 65:17801786.

Dethier, M. N., and D. O. Duggins. 1984. An "indirect commensalism" between marine herbivores and the importance of competitive hierarchies. American Naturalist 124:205219.

Drake, J. A. 1989. Biological invasions: a global perspective (SCOPE 37), J. Wiley, Chichester, New York, USA.

Dungan, M. L. 1986. Three-way interactions: barnacles, limpets, and algae in a Sonoran Desert rocky intertidal zone. American Naturalist 127:292-316.

Elner, R. W. 1981. Diet of green crab Carcinus maenas (L.) from Port Hebert, southwestern Nova Scotia. Journal of Shellfish Research 1:89-94.

Everett, R. A. 1989. The effects of seasonal blooms of algae and an unusual settlement of predaceous crabs, on the structure of an intertidal infaunal assemblage. Dissertation. University of California, Berkeley, California, USA.

Gee, J. M., R. M. Warwick, J. T. Davey, and C. L. George. 1985. Field experiments on the role of epibenthic predators in determining prey densities in an estuarine mudflat. Estuarine, Coastal, and Shelf Science 21:429-448.

Geller, J. B., E. D. Walton, E. D. Grosholz, and G. M. Ruiz. 1997. Cryptic invasion of Carcinus detected by molecular phylogeography. Molecular Ecology 6:901-906.

Goss-Custard, J. D. 1981. Role of winter food supplies in the population ecology of common British wading birds. Verhandlungen der Ornithologischen Gesellschaft in Bayern 23:125-146.

Griffiths, C. L., P. A. R. Hockey, C. van Erkom Schurink, and P. J. Le Roux. 1992. Marine invasive aliens on South African shores: implications for community structure and trophic functioning. South African Journal of Marine Science 12:713-722.

Grosholz, E. D. 1996. Contrasting rates of spread for introduced species in terrestrial and marine systems. Ecology 77: $1680-1686$.

Grosholz, E. D., and G. M. Ruiz. 1995. Spread and potential impact of the recently introduced European green crab, Carcinus maenas, in central California. Marine Biology 122:239-247.

Grosholz, E. D., and G. M. Ruiz. 1996. Predicting the impact of introduced marine species: lessons from the multiple invasions of the European green crab. Biological Conservation 78:59-66.

Groves, R. H., and F. di Castri. 1992. Biogeography of Mediterranean invasions. Cambridge University Press, Cambridge, UK. 
Hengeveld, R. 1989. Dynamics of biological invasions. Chapman and Hall, London, UK.

Holt, R. D. 1996. Adaptive evolution in source--sink environments: direct and indirect effects of density-dependence on niche evolution. Oikos 75:182-192.

Holt, R. D., and J. H. Lawton. 1994. The ecological consequences of shared natural enemies. Annual Review of Ecology and Systematics 25:495-520.

Jensen, K. T., and J. N. Jensen. 1985. The importance of some epibenthic predators on the density of juvenile benthic macrofauna in the Danish Wadden Sea. Journal of Experimental Marine Biology and Ecology 89:157-174.

Kimmerer, W. J., E. Gartside, and I. J. Orsi. 1994. Predation by an introduced clam as the likely cause of substantial declines in zooplankton in San Francisco Bay. Marine Ecology Progress Series 113:81-93.

Kneib, R. 1988. Testing for indirect effects of predation in an intertidal soft-bottom community. Ecology 69:17951805.

Lambert, W. J., P. S. Levin, and J. Berman. 1992. Changes in the structure of a New England (USA) kelp bed: the effects of an introduced species? Marine Ecology Progress Series 88:303-307.

Le Roux, P. J., G. M. Branch, and M. A. P. Joska. 1990. On the distribution, diet and possible impact of the invasive European shore crab Carcinus maenas (L.) along the South African coast. South African Journal of Marine Science 9 : 85-93.

Louda, S. M., D. Kendall, J. Connor, and D. Simberloff. 1997. Ecological effects of an insect introduced for the biological control of weeds. Science 277:1088-1090.

MacIsaac, H. J. 1996. Potential abiotic and biotic impacts of zebra mussels on the inland waters of North America American Zoologist 36:287-299.

MacPhail, J. S., E. I. Lord, and L. M. Dickie. 1955. The green crab-a new clam enemy. Fisheries Research Board of Canada, Atlantic Progress Report 63:3-12.

Malinowski, S. M., and R. B. Whitlach. 1983. Natural survivorship of young hard clams, Mercenaria (Linne) in eastern Long Island Sound. National Shellfisheries Association (Abstract), Hanover, Pennsylvania, USA

Martin, T. H., R. A. Wright, and L. B. Crowder. 1989. Nonadditive impact of blue crabs and spot on their prey assemblages. Ecology 70:1935-1942.

Menge, B. A. 1995. Indirect effects in marine rocky intertidal interaction webs: patterns and importance. Ecologica Monographs 65:21-74.

Menge, B. A. 1997. Detection of direct versus indirect effects: were experiments long enough? American Naturalist 149:801-823.

Mitchell, R. J. 1992. Testing evolutionary and ecological hypotheses using path analysis and structural equation modelling. Functional Ecology 6:123-129.

Mooney, H. A., and J. A. Drake. 1986. Ecology of biological invasions of North America and Hawaii. Ecological Studies 58, Springer-Verlag, New York, New York, USA

Moyle, P. 1986. Fish introductions into North America: patterns and ecological impact. Pages 27-43 in H. A. Mooney and J. A. Drake, editors. Ecology of biological invasions of North America and Hawaii, Springer-Verlag, Berlin, Germany.

Moyle, P. B., and R. L. Leidy. 1992. Loss of biodiversity in aquatic ecosystems: evidence from fish faunas. Pages 127 170 in P. L. Feidler and S. K. Jain, editors. Conservation biology: the theory and practice of nature conservation, preservation, and management. Chapman and Hall, New York, New York, USA.

Nichols, F. H., J. K. Thompson, and L. E. Shemel. 1990. Remarkable invasion of San Francisco Bay (California, USA) by the Asian clam Potamocorbula amurensis. II. Dis- placement of a former community. Marine Ecology Progress Series 66:95-101.

Ogutuohwayo, R. 1990. The decline of the native fishes in lakes Victoria and Kyoga (East Africa) and the impact of introduced species, especially the Nile perch, Lates niloticus, and the Nile tilapia, Oreochromis niloticus. Environmental Biology of Fishes 27:81-96.

Ogutuohwayo, R., and R. E. Hecky. 1991. Fish introductions in Africa and some of their implications. Canadian Journal of Fisheries and Aquatic Sciences 48:8-12.

Onuf, C. P. 1987. The ecology of Mugu Lagoon, California: an estuarine profile. U.S. Fish and Wildlife Service Biological Reports 85 (7.15), Washington, D. C., USA.

Pedazur, E. J. 1982. Multiple regression in behavioral research. Holt, Rinehart, and Winston. New York, New York, USA.

Peterson, C. H. 1982. The importance of predation and intraand interspecific competition in the population biology of two infaunal suspension feeding bivalves Protothaca staminea and Chione undatella. Ecological Monographs 52: 439-475.

Polis, G. A., and S. D. Hurd. 1996. Allochthonous input across habitats, subsidized consumers, and apparent trophic cascades: examples from the ocean-land interface. Pages 275-285 in G. A. Polis and K. O. Winemiller, editors. Food webs, integration of patterns and dynamics, Chapman and Hall, New York, New York, USA.

Polis, G. A., and D. R. Strong. 1996. Food web complexity and community dynamics. American Naturalist 147:813846.

Por, F. D. 1978. Lessepsian migration: the influx of Red Sea biota into the Mediterranean by way of the Suez Canal. Springer-Verlag, Berlin, Germany.

Posey, M. H. 1988. Community changes associated with the spread of an introduced seagrass, Zostera japonica. Ecology 69:974-983.

Posey, M. H., and A. H. Hines. 1991. Complex predatorprey interactions within an estuarine benthic system. Ecology 72:2155-2169.

Posey, M. H., C. Wigand, and J. C. Stevenson. 1993. Effects of an introduced aquatic plant, Hydrilla verticillata, on benthic communities in the upper Chesapeake Bay. Estuarine, Coastal, and Shelf Science 37:539-555.

Power, M. E. 1990. Effects of fish in river food webs. Science 250:811-814

Power, M. E. 1992. Top-down and bottom-up forces in food webs: do plants have primacy? Ecology 73:733-746.

Race, M. S. 1982. Competitive displacement and predation between introduced and native mud snails. Oecologia 54: 337-347.

Raffaelli, D., A. Conacher, H. McLachlan, and C. Emes. 1989. The role of epibenthic crustacean predators in an estuarine food web. Estuarine, Coastal, and Shelf Science 28:149160.

Rangeley, R. W., and M. L. H. Thomas. 1987. Predatory behavior of juvenile shore crab Carcinus maenas (L.). Journal of Experimental Marine Biology and Ecology 108:191197.

Reise, K. 1977. Predator exclusion experiments in an intertidal mud flat. Helgolander wissenschaftliche Meeresuntersuchungen 30:263-271.

Reise, K. 1978. Experiments on epibenthic predation in the Wadden Sea. Helgolander wissenschaftliche Meeresuntersuchungen 31:55-101.

Reise, K. 1979. Moderate predation on meiofauna by the macrobenthos of the Wadden Sea. Helgolander Meeresuntersuchungen 32:453-465.

Rhoads, D. C., and D. K. Young. 1970. The influence of deposit-feeding organisms on sediment stability and com- 
munity trophic structure. Journal of Marine Research 28: $150-178$.

Rhoads, D. C., and D. K. Young. 1971. Animal-sediment relations in Cape Cod Bay, Massachusetts. II. Reworking by Molpadia oolitica (Holothuroidea). Marine Biology 11: 255-261.

Ronan, T. E. 1975. Structural and paleoecological aspects of a modern soft-sediment community: an experimental field study. Ph.D. Dissertation. University of California, Davis, CA, USA.

Ropes, J. W. 1968. The feeding habits of the green crab, Carcinus maenas (L.). Fishery Bulletin 67:183-203.

Ropes, J. W. 1988. The food habits of five crab species at Pettaquamscutt River, Rhode Island. Fishery Bulletin 87: 197-204.

Ruiz, G. 1987. Interactions among shorebirds, crab, and their invertebrate prey populations. Dissertation. University of California, Berkeley, CA, USA.

Ruiz, G. M., J. T. Carlton, E. D. Grosholz, and A. H. Hines. 1997. Global invasion of marine and estuarine habitats by non-indigenous species: mechanisms, extent, and consequences. American Zoologist 37:619-630.

Ruiz, G., P. G. Connors, S. E. Griffin, and F. A. Pitelka. 1989. Structure of a wintering Dunlin population. Condor 91 : 562-570.

Sanchez-Salazar, M. E., C. L. Griffiths, and R. Seed. 1987. The interactive roles of predation and tidal elevation in structuring populations of the edible cockle, Cerastoderma edule. Estuarine, Coastal, and Shelf Science 25:245-260.

Schemske, D. W., and C. C. Horvitz. 1988. Plant-animal interactions and fruit production in a neotropical herb: a path analysis. Ecology 69:1128-1137.

Scherer, B., and K. Reise. 1982. Significant predation on micro- and macrobenthos by the crab Carcinus maenas $\mathrm{L}$. in the Wadden Sea. Kieler Meeresforschungen Sonderheft 5:490-500.

Schmitt, R. 1987. Indirect interactions between prey: apparent competition, predator aggregation, and habitat segregation. Ecology 68:1887-1897.

Schoener, T. W. 1989. Food webs from the small to the large. Ecology 70:1559-1589.

Schoener, T. W. 1993. On the relative importance of direct versus indirect effects in ecological communities. Pages 365-411 in H. Kawanabe, J. E. Cohen, and K. Iwasake, editors. Mutualism and community organization: behavioral, theoretical, and food-web approaches. Oxford University Press, Oxford, UK.

Schoener, T. W., and D. A. Spiller. 1996. Devastation of prey diversity by experimentally introduced predators in the field. Nature 381:691-694.

Simberloff, D., and P. Stiling. 1996. How risky is biological control? Ecology 77:1965-1974.

Sokal, R. R., and F. J. Rohlf. 1981. Biometry. W. H. Freeman, San Francisco, California, USA.

Strauss, S. Y. 1991. Indirect effects in community ecology: their definition, study, and importance. Trends in Ecology and Evolution 6:206-210.
Strong, D. R. 1992. Are trophic cascades all wet? Differentiation and donor-control in speciose ecosystems. Ecology 73:747-754.

Strong, D. R. 1997. Quick indirect interactions in intertidal food webs. Trends in Ecology and Evolution 12:173-174.

Townsend, C. 1996. Invasion biology and ecological impact of brown trout Salmo trutta in New Zealand. Biological Conservation 78:13-22.

Underwood, A. J., and E. L. Denley. 1984. Paradigms, explanations, and generalizations in models for the structure of intertidal communities on rocky shores. Pages 151-180 in D. R. Strong, D. Simbeloff, L. G. Abele, and A. B. Thistle, editors. Ecological communities: conceptual issues and the evidence. Princeton University Press, Princeton, New Jersey, USA.

Vermeij, G. J. 1991a. When biotas meet: understanding biotic interchange. Science 253:1099-1104.

Vermeij, G. J. 1991b. Anatomy of an invasion: the transArctic interchange. Paleobiology 17:281-307.

Vitousek, P. M., C. M. D'Antonio, L. L. Loope, and R. Westbrooks. 1996. Biological invasions as global environmental change. American Scientist 84:468-478.

Warnock, N., and M. A. Bishop. 1998. Spring stopover ecology of migrant Western Sandpipers. Condor 100:456-467.

Warnock, N., G. W. Page, and B. K. Sandercock. 1997. Local survival of Dunlin wintering in California. Condor 99:906915.

Warnock, N., G. W. Page, and L. E. Stenzel. 1995. Nonmigratory movements of Dunlins on their California wintering grounds. Wilson Bulletin 107:131-139.

Werner, E. E., and B. R. Anholt. 1996. Predator-induced behavioral indirect effects: consequences to competitive interactions in anuran larvae. Ecology 77:157-169.

Wilbur, H. M., and J. E. Fauth. 1990. Experimental aquatic food webs: interactions between two predators and two prey. American Naturalist 135:176-204.

Winer, B. J., D. R. Brown, and K. M. Michels. 1991. Statistical principles in experimental design. Third edition. McGraw-Hill, New York, New York, USA.

Woodin, S. A. 1979. Interphyletic competition among marine benthos. American Zoologist 19:1029-1043.

Woodin, S. A. 1981. Disturbance and community structure in a shallow water sand flat. cology 62:1052-1066.

Wootton, J. T. 1992. Indirect effects, prey susceptibility, and habitat selection: impacts of birds on limpets and algae. Ecology 73:981-991.

Wootton, J. T. 1993. Indirect effects and habitat use in an intertidal community: interaction chains and interaction modifications. American Naturalist 141:71-89.

Wootton, J. T. 1994a. The nature and consequences of indirect effects in ecological communities. Annual Review of Ecology and Systematics 25:443-466.

Wootton, J. T. 1994b. Predicting direct and indirect effects: an integrated approach using experiments and path analysis. Ecology 75:151-165.

Yodzis, P. 1988. The indeterminacy of ecological interactions as perceived through perturbation experiments. Ecology 69:508-515. 